\title{
Social inequalities and famine and severe food insecurity risk
}

\author{
Becky Carter and Luke Kelly \\ Institute of Development Studies and University of Manchester \\ 30 June 2021
}

\section{Question}

In what ways are social inequalities and discrimination (relating to gender; age; disability; sexual orientation, gender identity and/or expression, and sex characteristics; ethnicity; and religious belief) drivers of famine or severe food insecurity risk at the national, sub-national, household and individual levels? Look at evidence on vulnerability and resilience. What measures address these drivers?

\section{Contents}
1. Summary
2. Key concepts and analytical approaches
3. Disaggregated data and early warning systems
4. Social inequalities and national/sub-national risk
5. Social inequalities and individual or household risk
6. Measures
7. References other Government departments, but the views and opinions expressed do not necessarily reflect those of FCDO, the UK Government, K4D or any other contributing organisation. For further information, please contact helpdesk@k4d.info. 


\section{Summary}

This rapid review summarises the evidence on the ways in which social inequalities and discrimination affect the risk of famine or severe food insecurity. Looking at the risk at the national and sub-national level, gender and other horizontal inequities can affect a society's risk of violent conflict and therefore food insecurity, while fragile livelihoods associated with ethnic marginalisation can impact on regional food security. At the individual and household level, there is a lack of disaggregated data on people's social characteristics and famines. There is a broader literature on the impact of systemic discrimination (based on gender, age, disability, sexuality, and ethnic identity) on individuals' and households' livelihoods and assets, thereby increasing their vulnerability to food insecurity. A key finding from the literature is the gender gap, with women more at risk of being food insecure than men. Also, some ethnic groups are highly vulnerable particularly in conflict-related famines; starvation is used as a warfare tactic in political and ethnic conflicts. There is evidence of how social inequalities heighten individuals' risks during food crises and famines, including through exposure to protection threats, while limiting their access to essential services and humanitarian assistance. A broad range of measures seek to address the multi-dimensional ways in which social inequalities affect vulnerability and resilience to food insecurity.

Report focus, scope and structure: This rapid literature review focuses on inequalities arising from the discrimination of people based on their gender; age; disability; sexual orientation, gender identity and/or expression, and sex characteristics; and religious belief. The review has looked for evidence on how these inequalities have affected vulnerability and resilience to famine and severe food insecurity in particular in Afghanistan, Burkina Faso, the Central African Republic, the Democratic Republic of Congo, Ethiopia, Nigeria, Somalia, South Sudan, Sudan, Syria and Yemen. This is a rapid review that provides an illustrative selection of research, with the aim of showing the range of evidence available and key findings in the literature. The resources included in this report were identified through a non-systematic desk-based search of English language materials and suggestions from several experts. The evidence is presented in five sections: the key concepts and analytical frameworks; disaggregated data and early warning systems; national and sub-national risk of famine or severe food insecurity; individual and household risk of famine or severe food insecurity; measures addressing these.

Evidence base: There is limited disaggregated data and analysis on the impact of social inequalities and discrimination on people's vulnerability to, and during, famines. There is a larger literature on socially determined vulnerabilities and food insecurity risk, including severe food insecurity. There is substantial research and analysis on the differential enjoyment of food security by women and men; some evidence on differences by livelihood, ethnicity, geographic and residential status (rural/urban, settled/transitory/displaced); and less on the differences in food security due to discrimination by age, disability, and sexuality. It was difficult to find research on religious identity and food insecurity. This review found a range of literature to draw on, including 1) academic research on famine, including theoretical frameworks and in-depth case studies; 2) peer reviewed articles, independent evaluations and a large grey literature analysing women's vulnerability to food insecurity across countries, or across crisis events, and much less on other groups; and 3) humanitarian vulnerability assessments in food crises (involving severe food insecurity and famine conditions). Humanitarian organisations have also produced substantial guidance on vulnerabilities and risks faced by groups of people during humanitarian crises, including food insecurity emergencies, and how to mitigate these. 


\section{Key findings}

Key concepts and analytical frameworks: Famine and severe food insecurity are multidimensional, interrelated concepts. Food security means all people have at all times access to sufficient, safe, and nutritious food ${ }^{1}$, while food insecurity can be understood as a continuum, with starvation the most extreme experience (Hendriks, 2015). The Integrated Food Security Phase Classification (IPC) sets out the criteria for the widely agreed classification of "famine", which involves "(s)tarvation, death, destitution and extremely critical levels of acute malnutrition" (IPC, 2020: 1). Research provides insights into famine as a process, a system, and a unique state characterised by social breakdown (key contributions from Devereux, Howe, and Maxwell among others). Food insecurity risk is an outcome of individuals' and households' vulnerability and resilience, which are shaped by social inequalities and discrimination. Food security vulnerability assessments draw on the Sustainable Livelihoods Framework (DFID, 1999), with a recent interest in applying an intersectional approach to understand individual risks in a crisis.

Disaggregated data and early warning systems: Data on individuals' vulnerability and resilience at times of severe food insecurity and (particularly in) famines is scarce. The humanitarian sector aims to improve the collection of disaggregated data to understand how crises have differential impacts on people and the effect of social inequalities. However, despite the increase of guidance and learning resources in recent years, key food security and famine early warning systems tend not to include data on individuals and social categories.

Looking at famine or severe food insecurity risk at the national and sub-national level:

- Food insecurity is both an effect and cause of conflict while in recent years the worst food crises have occurred in areas of active conflict (Messer \& Cohen, 2004; Elver, 2020).

- Gender inequalities, in particular women's vulnerability to violence, influence a "country's propensity for violent conflict" (United Nations \& World Bank, 2018: 116). High levels of economic and political inequalities experienced by ethnic, regional and religious groups can "make violent conflict more likely", with perceptions of inequalities important (Bahgat et al., 2017: 185). Experts highlight evidence gaps and complex interlinkages of causal factors (Birchall, 2019; Bahgat et al., 2017).

- Vulnerability of pastoralist livelihoods impacts on Africa's national and regional economies (FAO, 2018a).

- Global tracking of countries' humanitarian risk takes social inequalities into account.

Looking at the ways in which social inequalities contribute to individual/household risk of famine or severe food insecurity:

Drivers of vulnerability:

- Who is vulnerable in a famine tends to be context specific: this requires careful analysis, including of the causes of famine (Howe, 2018: 148; Devereux et al., 2017: 3).

- Vulnerability to severe food insecurity and famine is affected by 1) underlying chronic food insecurity and undernutrition, 2) susceptibility (e.g. dependency on a single livelihood), and 3) limited assets affecting individuals' and households' ability to withstand potential disruptive factors (Howe, 2018: 146).

\footnotetext{
${ }^{1}$ https://www.ifpri.org/topic/food-security [Accessed 24 June 2021]
} 
- Evidence shows that systematic discrimination and marginalisation by gender, age, disability, sexuality and ethnicity impacts negatively on people's livelihoods and assets, making them more vulnerable to food insecurity, and at times severe food insecurity. Notably, there is substantial research on women's higher level of vulnerability to food insecurity compared to men's, "even when they have the same income and education levels and live in similar areas as men" (FAO et al., 2020: 24).

- The literature highlights the importance of ethnicity as a factor affecting vulnerability in famines. In situations of conflict driven by political, ethnic and/or religious tensions and factionalism, starvation of civilians may be used as a method of warfare.

Risks: Research on malnutrition, morbidity and mortality during famines provides an insight into the heightened vulnerabilities by age, gender, displacement status, and minority ethnic groups (but there appears to be little evidence on the impact of disability, sexuality and religious identity):

- Mortality rates point to high risks for children, young infants and elderly during famines, however "adults and adolescents also die in large numbers" (Devereux et al., 2017: 12; Devereux, 2000: 10). Women consistently experience lower death rates in famines, but in some famines girls had higher mortality rates than boys (Devereux, 2000: 11).

- Nutrition is critical for prenatal/lactating women and infants with women more vulnerable to inadequate nutrition in food shortages (de la O Campus \& Garner, 2014: 7).

- In addition, displaced people and minority ethnic groups are often more at risk.

Access to services and humanitarian assistance: The evidence shows social inequalities and discrimination can impede access to basic services in food secure situations; in food crises these inequalities tend to be exacerbated. Socially constructed barriers affecting access to services and humanitarian assistance can be environmental, institutional and/or attitudinal.

\section{Exposure to protection threats:}

- Negative coping mechanisms during food crises have particular risks for women and girls, for example, pressure for girls to marry young (de la O Campos \& Garner, 2014).

- Displacement heightens risks of deprivation; women, children, elderly, people with disabilities and minority ethnic groups are overrepresented in displaced populations.

- Women and girls are vulnerable to gender-based violence in times of severe food insecurity, through increases in domestic violence; transactional sex; and sexual exploitation and abuse by aid workers and other food aid distributors (Fraser, 2020).

- Minority groups and children, especially children with disabilities, face protection threats.

- Intersectional inequalities can heighten vulnerability: women and girls with disabilities and/or from a minority ethnic group are more at risk of conflict related sexual violence.

There are a wide range of measures to address these issues, including interventions on: 1) food crisis monitoring and analysis; 2) financing and delivery of humanitarian assistance; 3) civil society engagement and accountability to affected populations, including protection from sexual exploitation and abuse at all levels of the humanitarian system; 4) diplomacy relating to conflict prevention, respect for International Humanitarian Law and humanitarian access; 5) resilience, looking at social protection and women's empowerment. 


\section{Key concepts and analytical approaches}

Setting the framework for this review is challenging because famine and food insecurity are two related, multi-dimensional, complex concepts, for which there are a range of analytical models.

\section{Definitions of food insecurity and famine}

Measures of food insecurity ${ }^{2}$ include the FAO's Food Insecurity Experience Scale ${ }^{3}$ which finds that people experiencing severe levels of food insecurity go for entire days without eating.

A famine is declared if certain criteria are reached. According to the predominant global system for classifying famines - the Integrated Food Security Phase Classification (IPC), ${ }^{4}$ famine is "an extreme deprivation of food. Starvation, death, destitution and extremely critical levels of acute malnutrition are or will likely be evident" (IPC, 2020: 1). A Phase 5 famine classification (the highest phase of the IPC Acute Food Insecurity scale) "is attributed when an area has at least $20 \%$ of households facing an extreme lack of food, at least $30 \%$ of children suffering from acute malnutrition, and two people for every 10,000 dying each day due to outright starvation or to the interaction of malnutrition and disease" (IPC, 2020: 1).

However, before the IPC area-based criteria for a famine are reached, individuals and households may experience famine-like conditions. Recognising this, IPC may classify households as in IPC Phase 5 Catastrophe to highlight the households that "have an extreme lack of food and/ or other basic needs even after full employment of coping strategies", even if the area has not met the criteria of IPC Phase 5 Famine (IPC Global Partners, 2019: 87). In June 2021, "assessments show that tragically, 584,000 are already experiencing famine-like conditions (IPC phase 5/Catastrophe) in Ethiopia, Madagascar, South Sudan and Yemen. Nigeria and Burkina Faso are also of particular concern because they have in recent months had pockets of people in IPC phase 5". ${ }^{5}$ There are political pressures on the data; governments can be reluctant to declare a famine under their administration (Maxwell \& Hailey, 2020: 8).

This rapid review has not found an agreed definition of "risk of famine"6. In June 2021 WFP reported that the 41 million people in 43 countries (arise from 27 million in 2019) in the preceding phase (IPC phase 4/Emergency) are "teetering on the very edge of famine ... and the slightest

\footnotetext{
2 It is also pertinent to consider the definition of food security: "Food security, as defined by the United Nations' Committee on World Food Security, means that all people, at all times, have physical, social, and economic access to sufficient, safe, and nutritious food that meets their food preferences and dietary needs for an active and healthy life." https://www.ifpri.org/topic/food-security [Accessed 24 June 2021]
}

The World Summit on Food Security in 2009 identified four pillars of food security - availability, access, utilisation and stability. http://www.fao.org/wsfs/wsfs-list-documents/en/ [Accessed 24 June 2021]

${ }^{3} \mathrm{http}: / /$ www.fao.org/in-action/voices-of-the-hungry/fies/en/ [Accessed 22 June 2021]

${ }^{4}$ http://www.ipcinfo.org/ [Accessed 24 May 2021]

${ }^{5}$ https://www.wfp.org/news/wfp-says-41-million-people-now-imminent-risk-famine-without-urgent-funding-andimmediate [Accessed 26 June 2021]

${ }^{6}$ Koch and Fuhrman (2019) report that "(t)he global IPC community is in the process of agreeing on the definition of risk of famine". 
shock will push them over the precipice". ${ }^{7}$ In 2020 a FAO-WFP early warning analysis of acute food insecurity hotspots where "any further deterioration over the coming months could lead to a risk of famine" were selected based on parameters of: (WFP \& FAO, 2020: 6)

- "Assessed levels of recent or current food insecurity and malnutrition with a focus on acute food insecurity - and deterioration in comparison to pre-COVID-19 times;

- Three to six month projections of acute food insecurity situations based on analysis of primary and secondary drivers ...;

- Presence of natural hazard risks, economic risks and conflict risks that are likely to drive food insecurity levels further up ...;

- Dependence on commodity exports, food imports and remittances;

- Planned and ongoing agricultural activities during the October-December period and existing or likely disruptions by impacts of COVID-19-related restrictions;

- Presence of particularly vulnerable or at-high-risk populations including women, Internally Displaced Persons (IDPs), refugees, migrants and asylum seekers, and others;

- Presence of operational and humanitarian access constraints".

\section{Analytical frameworks}

\section{Food insecurity}

International humanitarian actors tend to understand food insecurity as a continuum, in which starvation is the most extreme experience (Hendriks, 2015).

The linkages between the different dimensions of food insecurity are complex. Food insecurity can be understood by both its duration and its severity. Devereux (2006: xi) suggests a 2x2 classification: "moderate chronic (e.g. chronic hunger); severe chronic (for instance, using high infant mortality and child mortality rates as proxies); moderate transitory (e.g. the annual "hungry season' in tropical agriculture); and severe transitory (food crises)".

\section{Famines}

The literature on famines describes how theories of causality have developed over time:

- from food production shortfalls (through drought, flood, pest) seen as the primary cause of famines;

- to Amartya Sen's entitlement theories in the 1980s focusing on the social and economic ability to access food, which highlighted "social differentiation in cause and outcome of vulnerability” to famine (Adger, 2006: 271; Howe, 2018: 145);

- to an appreciation of "the salience of politics, historical processes and social disruption in creating conditions of vulnerability and famine" especially in conflict situations (Baro \& Deubel, 2006: 524, citing Alex de Waal among others).

\footnotetext{
${ }^{7}$ https://www.wfp.org/news/wfp-says-41-million-people-now-imminent-risk-famine-without-urgent-funding-andimmediate [Accessed 26 June 2021]
} 
Famine, once understood primarily as an event, is now explored in the research as a process. Howe and Devereux (2004: 366) explain famine as "an accelerated process of rising individual malnutrition, household destitution and social breakdown." Howe (2018: 145) "emphasizes systems thinking", suggesting "it is the interaction of factors in a system, rather than a simple linear sequence of stages, that characterizes the evolution of a famine". He highlights "synergistic interactions among different elements that lead to the rapid shifts that characterize famines: the price spirals, the rise in malnutrition and mortality, and the intensive responses, after which interest and support taper off". The literature also highlights famine is "a distinct state" characterised by social disruption - that is "qualitatively different from other forms of extreme food insecurity", and therefore not to be understood as "the extreme of a continuum of underdevelopment, measurable simply by poverty" (Rivers et al., 1976: 346; Howe \& Devereux, 2004: 366).

\section{Vulnerability and resilience}

Food insecurity risk can be understood as an outcome of vulnerability and resilience, which is socially determined. DG ECHO (2016: 10) defines vulnerability as the "(I)ife circumstances (e.g. poverty, education) and/or discrimination based on physical or social characteristics (sex, disability, age, ethnicity, religion, sexual orientation, etc.) reducing the ability of primary stakeholders (for example, individuals/households/community) to withstand adverse impact from external stressors". ${ }^{8}$ Looking more specifically at vulnerability, or lack of resilience, to food insecurity, Howe identifies three critical pathways affecting "the susceptibility of certain populations to experiencing food security and nutrition crises":

1) "underlying chronic food insecurity and undernutrition, which disruptive factors can accelerate rapidly into famine conditions".

2) "an expression of susceptibility to potential disruptive factors. For instance, if a community is dependent on a single livelihood, such as rain-fed agriculture, its food security and nutrition is more easily disrupted by a drought, creating greater vulnerability".

3) "a function of a limited capacity, in terms of assets, to withstand a combination of disruptive factors".

Vulnerability and resilience analyses are used to identify individuals, households and communities who may become severely food insecure in a particular context:

- A key approach is the Sustainable Livelihoods Framework, conceptualised by DFID in 1999 and widely used by humanitarian actors. It allows a holistic appreciation of the factors shaping households' livelihood strategies, differential asset accumulation (including human, natural, physical, financial, social capital), and vulnerability (Carter, 2021: 5, citing Levine \& Sharp, 2015).

- There is growing focus on using intersectional vulnerability analysis to understand individual needs and risks in a crisis, moving beyond a homogenous group

\footnotetext{
8 This summary is taken from Carter (2021) which provides an overview of the literature on the impact of social inequalities on vulnerability to crises.
} 
categorisation (Kuran et al., 2020). Broader research highlights how in everyday life and in crises - social inequalities and discrimination along gender, age, disability, sexuality, ethnicity and religious lines result in overlapping, compounding disadvantages, shaping each person's individual experience (Carter, 2021).

\section{Disaggregated data and early warning systems}

Humanitarian vulnerability assessments identify which individuals and households affected by social inequalities and discrimination are more vulnerable to severe food insecurity. For example, in $2021 \mathrm{OCHA}$ found in Syria that, with close to $90 \%$ of the population living below the poverty line of which $60-65 \%$ are estimated to live in extreme poverty, the "(I)evels of both moderate and severe food insecurity are particularly high among returnees, female-headed households, households with member/s with a disability, older persons and children" (OCHA, 2021b: 28). Moreover, the assessment concludes that "(w)hen gender, age and disability intersect in the Syrian context, individual and household vulnerability is notably compounded. In 2021 , it is these social determinants that most accurately indicate humanitarian needs and provide an in-depth understanding of broader geographical factors" (OCHA, 2021b: 31).

However, data on individuals' vulnerability and resilience in the lead up to and during severe food insecurity and (particularly in) famines is scarce. Famine risk analysis is a technically difficult and politically charged exercise, affected by serious logistical challenges in conflict and fragile settings; consequently, data is often missing ${ }^{9}$ (Maxwell \& Hailey, 2020: 22).

There is an aim in the humanitarian sector to improve data, including by collecting disaggregated data, as this is essential to understand how crises have differential impacts on people depending on their "sex or gender, age, disability, geography, ethnicity, religion, caste or any other factors" (Sphere Association, 2018: 12). Standards and guidelines for disaggregated humanitarian data collection, methodologies and processes are set out in the Core Humanitarian Standards on Quality and Accountability, ${ }^{10}$ the Sphere Handbook, ${ }^{11}$ the United Nations' Joint Intersectoral Analysis Framework (JIAF), ${ }^{12}$ the Interagency Standing Committee's (IASC) Gender Handbook for Humanitarian Action, ${ }^{13}$ and the IASC Guidelines on Inclusion of Persons with Disabilities in Humanitarian Action, ${ }^{14}$ among others.

However, despite the increase of guidance and learning resources in recent years, the collection and analysis of disaggregated humanitarian data is still sporadic. Key food security and famine

\footnotetext{
${ }_{9}^{9}$ Maxwell and Hailey (2020: 19) find that "(t)he three categories of data most frequently missing —at least for a substantial proportion of the areas analysed-included mortality data (South Sudan, Nigeria, Yemen, Kenya); baseline and updated population data (all country cases); displacement data (Ethiopia, Nigeria, South Sudan); and nutrition data (almost all cases)".

${ }^{10} \mathrm{https}: / /$ corehumanitarianstandard.org/the-standard [Accessed 17 June 2021]

${ }^{11}$ https://spherestandards.org/handbook-2018/ [Accessed 17 June 2021]

12 https://www.jiaf.info/ [Accessed 17 June 2021]

${ }^{13}$ https://www.gihahandbook.org/ [Accessed 17 June 2021]

${ }^{14} \mathrm{https}$ ://interagencystandingcommittee.org/iasc-task-team-inclusion-persons-disabilities-humanitarianaction/documents/iasc-guidelines [Accessed 17 June 2021]
} 
early warning systems do not include data on individuals and social categories; most data is on households, and sometimes on the head of the household. ${ }^{15}$ There is some gender disaggregated data from famines and severe food insecurity situations, but this remains patchy. Often gender is only available for malnutrition and mortality data (as found in South Sudan by Maxwell et al., 2018), while household level data does not allow insight into intra-household food equity dynamics. FAO et al. (2019: 91) conclude this "lack of data disaggregated by wealth quintile, gender, age, geography and disability ... poses a significant barrier to addressing inequality and tackling undernourishment and malnutrition in marginalized groups".

The Integrated Phase Classification Tool - which covers data on acute food insecurity, chronic food insecurity and acute malnutrition - dominates contemporary food security and famine analysis (Maxwell \& Hailey, 2020: 8; IPC Global Partners, 2019: 3). It provides an estimation of the scale and severity of food insecurity within a geographical area. The IPC aims to answer the question "(w)ho are those most affected?" to inform targeting of assistance (IPC Global Partners, 2019: 12). The IPC Integrated Food Security and Nutrition Conceptual Framework considers households' livelihood strategies and assets, with "(g)ender and other socio-economic inequalities and discrimination" identified as drivers of vulnerability (IPC Global Partners, 2019: 10-11). The IPC guidelines also specify identification of "household affected groups" distinguished "by variations in wealth, gender, ethnic affiliation, livelihood, religion, exposure to a hazard event, or any other factor or combination of factors that make these groups distinct" (IPC Global Partners, 2019: 51).

Reports of what is collected in practice using IPC analysis include:

- In South Sudan, Somalia, Nigeria and Yemen data showed if the household is male- or female-headed but with no intra-household data disaggregation (Kim et al., 2018).

- A report on IPC analysis in Sudan found the Food Security and Nutrition Monitoring System (FSNMS) "includes analysis on who accesses food distributions and who controls the decision making on use of food rations. It also analyses the gender protection issues related to food issues. However, there does not appear to be an analysis of the differential impact of food insecurity on gender or analysis of the implications of gender differences" (Maxwell et al., 2018: 25).

- A report on IPC data in Yemen found extremely limited attention to marginalised groups, with little quantitative or qualitative data, although a "fair amount of discussion occurs about social networks and indigenous support systems" (Maxwell et al., 2019: 24-25).

- In Somalia, South Sudan, Ethiopia, Nigeria, and Yemen, IPC and $\mathrm{CH}^{16}$ emphasis on "outcome indicator data (food security status, malnutrition, and mortality, as well as livelihood assets and coping strategies in complete analyses)" tends to "relegate data on causal factors to a secondary (and sometimes quite diminished) place in the analysis (Maxwell \& Hailey, 2020: 22).

\footnotetext{
15 https://www.devex.com/news/where-are-the-women-in-food-insecurity-analysis-98804 [Accessed 22 June 2021]

${ }^{16}$ Cadre Harmonisé is the regional framework used in West Africa. https://www.food-security.net/en/visualise/ [Accessed 22 June 2021] Maxwell and Hailey (2020: 13) describe $\mathrm{CH}$ as having a near identical format to IPC. and $\mathrm{CH}$ data is presented on the IPC platform: http://www.ipcinfo.org/ch [Accessed 21 June 20121]
} 
There are other early warning famine systems: briefly, here are some highlights of how they consider the relationship between social inequalities and famine risk:

- The USAID-funded Famine Early Warning System Network (FEWS NET) provides data on regions and livelihood zones within a country to predict food insecurity, using IPC classification. ${ }^{17}$ It works closely with IPC analysts but with "a different and more detailed approach to the early warning function" (Maxwell, 2019: 6). Scenario development for acute malnutrition and mortality includes questions on whether sub-groups - such as the poorest households, internally displaced persons, or flood-affected populations - are more affected than others (FEWS NET, 2018).

- The World Food Programme's Vulnerability Assessment and Mapping Unit conducts assessments and provides early warning (Maxwell, 2019: 7). WFP's Mobile Vulnerability Analysis and Mapping (mVAM) includes household data disaggregated by the gender of the head of household (WFP, 2015a). However, the 2020 evaluation of WFP's gender policy finds limited data collected for individuals (Peacocke et al., 2020: iv).

\section{Social inequalities and national/sub-national risk}

There appears to be little research exploring the ways in which social inequalities contribute to a national or sub-national risk of famine or severe food insecurity. There is some evidence on the relationship between some forms of social inequalities and the risk of national or sub-national conflict, and there is other research exploring the complex links between conflict and food insecurity. Experts caution there remain evidence gaps. Key findings from the evidence include:

Relationship between conflict and famines or severe food insecurity: Common drivers of recent famines have been a complex interaction of conflict and displacement, disasters and extreme weather, diseases and pests, economic shocks and high food prices, and inadequate/untimely humanitarian response (IPC, 2020: 2). In recent years "the worst food crises have occurred in areas of active conflict" (Elver, 2020: 11). Conflicts can become "food wars', not only because hunger is used as a weapon but also because food insecurity is both an effect and cause of conflict" (Messer \& Cohen: 2004: 1).

\section{Relationship between social inequalities, conflict, and risk of famine or severe food insecurity at the national/sub-national level:}

- Quantitative research shows that gender inequalities, and in particular women's vulnerability to violence, "is a significant predictor of the country's propensity for violent conflict overall" (United Nations \& World Bank, 2018: 116). Moreover discriminatory gender norms that underpin "unequal gendered roles and power relations" are proven to motivate support for and perpetuate conflict (Birchall, 2019: 3). Birchall's recent evidence summary stressed the importance of considering gender as a causal factor for conflict "inextricably linked with other factors, including weak or unaccountable governance, ethnic, communal and religious tensions, social exclusion, reduced livelihood, education

\footnotetext{
17 https://fews.net/ [Accessed 21 June 2021]
} 
and employment opportunities, lack of access to health care, security and justice, and land rights" (Birchall, 2019: 7). ${ }^{18}$

- Looking at the evidence on "inequalities based on group identities, such as ethnicity, region, and religion", Bahgat et al. (2017: 185) find "solid" evidence that "high levels of horizontal economic and political inequalities among the relatively deprived make violent conflict more likely". A small literature shows that perceptions of inequalities are important in attitudes towards violence, while "objective and perceived horizontal inequalities do not necessarily overlap" (Bahgat et al., 2017: 185). Relevant grievances can include competition over land and water (such as between pastoralists and crop producers), or a lack of economic opportunities (with youth unemployment "consistently cited in citizen perception surveys as a motive for joining both rebel movements and urban gangs" (International Development Association, 2020: 3)). However, "the conditions under which certain group identities become relevant for mobilizing people for violence is still clear" (Bahgat et al., 2017: iv).

\section{Vulnerability of livelihood groups and national and subnational level fragility and food insecurity: there is a body of research on how the vulnerability of marginalised pastoralist groups has an impact on regional food security in the Sudano-Sahel ecological zone ${ }^{19}$ (Jobbins \& McDonnell, 2021: 15; FAO, 2018a: 1). "The pastoral livestock value chain involves millions of herders, farmers, and businesses" and "plays an important role in the national and regional economies of Africa", through its contribution to household consumption, transport and domestic and international trade (Jobbins \& McDonnell, 2021: 7; FAO, 2018: 1). Therefore "(w)hen this system is disrupted by violence, forced displacement, or failed land management, the consequences ripple across the region, threatening food security and economic stability" (Jobbins \& McDonnell, 2021: 7).}

Global tracking of countries' humanitarian risk takes into account social inequalities (to a certain extent). For example, the global INFORM Risk Index ${ }^{20}$ ranks countries according to their risk levels for humanitarian crises. It takes into consideration how social inequalities may impact on national and subnational vulnerability to crises in two ways - directly by including data on vulnerable groups (including data on food insecurity) ${ }^{21}$ and by including data on development, deprivation and vertical inequality (Marin-Ferrer et al., 2017).

\section{Social inequalities and individual or household risk}

This section outlines the evidence on how social inequalities affect the vulnerability and resilience of individuals and households to famine and severe food insecurity. It summarises the literature on individual and household level 1) drivers of vulnerability to famine and food

\footnotetext{
18 This paragraph draws on a previous summary of this evidence in Carter (2021).

${ }^{19}$ A term used by Jobbins and McDonnell (2021: 3) to refer to: "(i) the Liptako-Gourma triangle at the intersection of Mali, Niger, and Burkina Faso; (ii) Nigeria and the Lake Chad Basin; (iii) the Central African Republic and surrounding border regions; and (iv) the Sudan/South Sudan border region".

20 https://drmkc.jrc.ec.europa.eu/inform-index/INFORM-Risk [Accessed 11 June 2021]

21 The vulnerable groups component includes data on "uprooted groups" and "others", the later with data on health conditions, children under 5 , recent shocks and food security, while gender inequality is included in the vertical inequality component (using the Gender Inequality Distribution data) (Marin-Ferrer et al., 2017).
} 
insecurity; 2) risks and access to essential services and humanitarian assistance; 3 ) exposure to protection threats related to food crises.

\section{Drivers of vulnerability}

The literature highlights the importance of careful contextual analysis to identify "the causes of famine vulnerability, and who is likely to be more vulnerable" (Devereux et al., 2017: 3; see also Howe, 2018: 148). Often the poorest people are at highest risk, but in some cases, particularly conflict-related famines, vulnerability has been "more complicated" (Devereux et al., 2017: 12). For example, "in Darfur in 1984, poor and rich were equally likely to be malnourished" while in the 1997 South Sudan famine "there was a strong correlation between initial wealth and famine mortality - as the richer were targeted for their asset wealth" (Devereux et al., 2017: 12).

Devereux (2006) and Howe (2018) unpack the drivers of vulnerability to famine at the household and individual level:

- Devereux (2006: xii) sets out how vulnerability and resilience are affected by "strong negative synergies between chronic and transitory food insecurity, and between moderate and severe food insecurity". Repeated transitory shocks can lead to chronic food insecurity as households use up or sell their assets until they "face destitution as well as heightened vulnerability to famine", while people who are already moderately food insecure are highly vulnerable to severe food insecurity when a shock occurs (Devereux, 2006: xii).

- Howe (2018: 146-147) looks at how interaction between vulnerability and disruptive factors that can result in a famine have a differential impact on households and communities depending on "economic, social, political, demographic, environmental, and biological characteristics". He finds at the outset of a famine, some individuals and households are more vulnerable due to "gender, age, disability and other diversity characteristics" or biological vulnerability especially for "young children, the elderly, and sometimes males" (Howe, 2018: 146). The "self-reinforcing dynamics" of a famine then "start to change the society in ways that further heighten and expose other forms of vulnerability (e.g. social marginalization of the elderly). The breakdown of traditions of communal sharing, the rise in crime, and the emotional and physical changes associated with hunger ramify outwards and have implications for who is most vulnerable during the crisis and for the heightening of that vulnerability" (Howe, 2018: 147).

Turning to look at the evidence on particular forms of social inequalities and vulnerability to famines and severe food insecurity, there is substantial evidence on how systematic discrimination and marginalisation based on gender, age, disability, sexuality and ethnic identity impacts negatively on people's livelihoods and assets, and in turn makes them more vulnerable to food insecurity, and at times severe food insecurity. In particular in famine contexts the literature highlights the importance of ethnicity as a factor affecting risk and vulnerability. It has been difficult to find evidence on the relationship between religious identity, social inequalities and food insecurity.

Research has shown how ethnicity can be an important factor. For example, social connections, often configured through ethnic identity, have been important in accessing land, irrigation and 
other resources vital to food security in Afghanistan (Lautze et al., 2002: 25-26). In Somalia local authorities use clan structures "to allocate resources and influence access to power, leading to marginalisation and exclusion of minority clans" (Lwanga-Ntale \& Owino, 2020: 6). Moreover, in situations of conflict driven by political, ethnic and/or religious tensions and factionalism, "starvation of civilians may be used as a method of warfare with famine conditions deliberately inflicted on certain groups" (Devereux, 2006: xii). For example, the international community has drawn attention to cases in Yemen, Syria and South Sudan ${ }^{22}$ (see also Human Rights Council, 2020), with concerns reported for Tigray, Ethiopia in June $2021^{23}$.

Key findings from the evidence include:

- The data shows women are more likely to be food insecure than men. Globally the prevalence of moderate or severe food insecurity is higher among women than men, a gender gap that increased from 2018 to 2019 (FAO et al., 2020: xx, 3). In-depth analysis of FAO 2014 to 2018 data from the Food Insecurity Experience Scale revealed women are more likely than men to find access to food difficult "even when they have the same income and education levels and live in similar areas as men"24 (FAO et al., 2020: 24). In particular female-headed households are often more vulnerable to shocks and food insecurity. ${ }^{25}$ There is an established evidence base linking women's increased vulnerability to food insecurity to gender inequities and multiple compounding disadvantages (Njuki et al., 2021). Key constraints are: 1) unequal access to and ownership of assets, including land rights and productive resources; 2) disproportionate representation in lower-paying, insecure jobs, with less autonomy over household decisions, or no income; and 3) discriminatory gender norms that restrict women's freedom of movement and burden women with the majority of unpaid caring responsibilities (Njuki et al., 2021; Brody et al., 2014: 21; Botreau \& Cohen, 2019: 8).

- FAO et al (2019: 100) find that "indigenous peoples are disproportionately represented among food-insecure and hungry populations", and "are often affected by poor food security and nutrition. They frequently live in extreme poverty and in environments that have been damaged; or they have lost their land and no longer have access to traditional food sources." Indigenous women are often among the most vulnerable populations, facing marginalisation within their own communities (FAO et al., 2019: 99).

- People with diverse sexual orientation, gender identity and/or expression, and sex characteristics are often "excluded from education and employment due to stigma and

\footnotetext{
22 https://starvationaccountability.org/resources/expert-report [Accessed 25 June 2021]

${ }^{23} \mathrm{https}: / /$ time.com/6076167/famine-tigray/ [Accessed 30 June 2021]

24 The study finds that: "After controlling for socio-economic characteristics, women still had about a 13 percent higher chance of experiencing moderate or severe food insecurity than men, and close to 27 percent higher chance of being severely food insecure at the global level" (FAO et al., 2020: 24). Moreover "The gender gap in food insecurity is larger among the poorer and less-educated strata of the population, and for individuals who are out of the workforce, with health problems and who live in suburbs of large cities compared with those who live in rural areas" (FAO et al., 2020: 24).

${ }^{25}$ For example, in Syria, the 2021 Humanitarian Needs Overview finds that "Female-headed households are less likely to be able to meet basic needs (one per cent adequate, 23 per cent fair) compared to overall (four per cent adequate, 31 per cent fair) and have experienced a steeper deterioration of their ability to do so in the past 12 months" (OCHA, 2021: 31).
} 
discrimination, with little chance to access the formal employment sector and the corresponding job security" (Bishop, 2020: 17). In many countries they "are disproportionately affected by poverty, homelessness and food insecurity" (MadrigalBorloz, 2018: 16). In a global study, House (2020: 8) found "a clear connection between discrimination against $\mathrm{LBT}+{ }^{26}$ communities and lack of access to decent work. The lack of access includes unemployment, as well as work that may be insecure, informal, unsafe, and/or poorly paid", and identify "an urgent need for further research on LBT+ poverty and its links with hunger, food insecurity and nutrition, as well as lack of shelter".

- "People with disabilities in [low and middle income countries], particularly women with disabilities, were already more likely to be living in poverty, and more likely to experience food insecurity" before the impacts of COVID-19 (Meaney-Davis, 2020: 5, citing UNDESA, 2019). While there is little research on people with mental disabilities' vulnerability to food insecurity, a community-based study in a rural Ethiopian district found households with people living with severe mental disorders (SMD) ${ }^{27}$ experienced more than twice as high levels of severe food insecurity than households from the general population (Tirfessa et al., 2017: 402-403). The study identified that possible factors included the impact on the household of caregiving taking away time available for food production and decreased community cooperation due to stigma.

- A survey conducted by HelpAge in humanitarian contexts showed that $64 \%$ of older people (over 50 years old) did not have enough to eat (McGivern, 2020: 4). For many poverty increases in older age with declining work opportunities and patchy access to pensions ${ }^{28}$, in particular for women (Juergens \& Galvani, 2020).

- Some children are particularly vulnerable to food insecurity: A resilience analysis of South Sudan finds that "(o)rphaned and other groups of vulnerable children, like girls and demobilized child soldiers, are an especially affected group within populations of humanitarian concern, due to their lack of sources of livelihoods, knowledge and skills, and thus their dependence on others" (WFP, 2015a: 55).

The literature also highlights that displaced people forced to leave their homes, livelihoods and resources face increased risk of food insecurity. They lose access to normal sources of food, work and shelter while facing novel threats (diseases, unsafe water, overcrowding) in their new environments (Devereux, 2000: 5). In Yemen 43\% of displaced households were unable to meet minimum food needs in September 2020 (WFP, 2020). Often women and children are displaced, while in some contexts marginalised ethnic minorities are disproportionately affected, such as by the Muhamasheen in Yemen (a historically marginalised group representing about $10 \%$ of the country's population) (Al-Warraq, 2019: 8; OCHA, 2021c: 32). People with disabilities are especially vulnerable during displacement: in a humanitarian displacement setting, JimenezDamary (2020: 15) finds households with people with disabilities "are more likely to experience

\footnotetext{
${ }^{26}$ Lesbians, bi women and trans people.

27 The study details SMD as including schizophrenia, schizoaffective disorder, bipolar disorder or severe depression/depression with psychotic features (Tirfessa et al., 2017).

28 They highlight that in "In Sub-Saharan Africa only 22 per cent of people above the retirement age receive a pension and large coverage gaps remain in Southern Asia (23 percent coverage) and the Arab States (27 percent) (Juergens \& Galvani, 2020).
} 
food insecurity, because they possess fewer economic resources and work opportunities, may require more health services and may incur extra costs and expenditure related to disability".

\section{Livelihoods}

Looking in more detail at some of the evidence specifically on livelihoods and food insecurity, the literature highlights that two major livelihood disruptors - conflict and climate change accentuate existing social inequalities and deepen vulnerabilities:

- Elver (2020: 11) finds "(p)rotracted conflict, local insecurity and violence disrupt agricultural production and threaten livelihoods, accentuating negative coping strategies and deepening vulnerability to shocks. Those who rely directly on the agricultural sector for their food and livelihood are particularly vulnerable and inequalities based on gender, age, location, race, ethnicity and migration status are accentuated". Elver (2017: 11) identifies that: "(i)n times of conflict, disadvantaged groups, such as children under 5 years of age, orphans, pregnant and lactating women, female-headed households, refugees and internally displaced persons, older persons, persons with disabilities, minorities and already marginalized communities suffering from social exclusion, tend to have less access to resources and the lowest coping capacities, leaving them most vulnerable to the risk of an inadequate diet. Pastoralists, nomadic peoples and indigenous communities are also vulnerable, with conflict having an impact on their access to land, fishing and hunting resources."

- Similarly "Climate change impacts differ among diverse social groups depending on factors such as age, ethnicity, ability/disability, sexual orientation, gender, wealth, and class" (Mbow et al., 2019: 446). Mbow et al. (2019: 446) find "(p)overty, along with socioeconomic and political marginalisation, cumulatively put women, children and the elderly in a disadvantaged position in coping with the adverse impacts of the changing climate". Looking at women's increased vulnerability, Women Deliver (2021: 1) find gender inequality results in "unequal access to basic social goods and natural and financial resources, reduction in food security, unequal decision-making power, and barriers in building capacity to increase individuals' resilience to extreme weather events".

The literature highlights the association between livelihoods and location - and in particular the degree of urbanisation - as a factor affecting vulnerability to food insecurity. Typically, people living in urban areas are more able to diversify livelihoods and have better access to food, while rural populations are much more vulnerable to climate stresses, and have fewer livelihood options (Devereux et al., 2017; Rao et al., 2019: 965).

In the case of rural pastoralist groups in the Horn of Africa, analysts draw attention to the complex political, economic and social processes of marginalisation that leaves them "increasingly vulnerable to malnutrition and food insecurity as their capacity to adapt to and recover from crises declines in the face of recurrent and often overlapping shocks. This was starkly illustrated in 2017 as Somalia veered towards famine" (FAO, 2018a: v; Pavanello, 2009: 8). Moreover "ethnic and religious divisions between pastoralist groups and others are sometimes used to justify exclusionary politics and escalate intercommunal conflicts" (Brottem \& McDonnell, 2020: 3) 
Meanwhile, those overrepresented in precarious livelihoods (often in the informal sector) or unemployed, including in urban areas, are more likely to lose their jobs when there is an economic downturn, and have fewer resources and assets to cope with a sudden loss of income (Carter, 2021: 7; see also FAO et al., 2019: 99). For example, looking at COVID-19, evidence shows that people affected by pre-crisis economic marginalisation have been more susceptible to, and have less resilience to cope with, the negative economic impacts in low and middleincome countries, leaving them more vulnerable to food insecurity. This includes "people with disabilities, refugees and internally displaced persons, the elderly, and women, adolescents and children". ${ }^{29}$ Rohwerder (2020) summarises the available evidence. Some examples are:

- A high proportion of women in low- and middle-income countries work in the informal sector, hit by high job losses during the pandemic (Meaney-Davis, 2020). As a result of income loss, "(s)ince the global pandemic began, female-headed households have significantly higher prevalence of moderate and/or severe food insecurity than maleheaded households" across Ethiopia, Malawi, Nigeria, and Uganda (Josephson et al., 2020: 6).

- Meaney-Davies (2020: 5) highlights "substantial evidence that many people with disabilities in LMICs are currently experiencing loss of work and income, extreme financial hardship and food insecurity" as a result of COVID-19 impacts, with those working in the informal sector or already experiencing extreme poverty "particularly severely impacted." She cites evidence from multiple countries.

- ILGA World (2020: 3) finds that "in South Africa, many migrants have escaped there in order to flee persecution for their sexual orientation, gender identity or expression in their home countries. Many of the migrants rely on jobs in the service industry and have been unable to find jobs during the lockdown".

\section{Unequal access to assets}

The research highlights the link between social inequalities in secure land tenure and resulting food insecurity for rural communities, indigenous people, women and marginalised groups (von Grebmer et al., 2020: 26; Berkhout, 2021: 43). While "rural women account for nearly half the agricultural workforce" in lower income countries (Botreau \& Cohen, 2019: 8), less than $15 \%$ of landowners are women across the world, and women are less likely to have the right to manage, transfer or derive economic benefits from land (FAO, 2018b). Meanwhile, in a range of countries there is ongoing displacement of smallholder farmers, pastoralists, and indigenous people in the face of land and clearing for commercial agriculture (von Grebmer et al., 2020: 26).

Access to credit is important to fund consumption during shocks; people affected by social inequalities and discrimination continue to face barriers in accessing credit, with evidence in the literature for women (Brody et al., 2014). and people with disabilities ("for example in some countries more than 30 percent of banks were not accessible to people with disabilities prior to the pandemic" (Meaney-Davis, 2020: 5, citing UNDESA, 2019: 3)).

\footnotetext{
29 https://publications.parliament.uk/pa/cm5801/cmselect/cmintdev/292-secondary-impacts/29207.htm\#footnote-
} 120 [Accessed 26 June 2021] 
Discrimination can mean some people do not have access to social networks and support, increasing their vulnerability to food insecurity. Research on famine and HIV/AIDS in Africa in the 1990 s led to a deeper understanding of coping strategies when households face hunger (Hendriks, 2015: 613). More recent work has highlighted the importance of social capital and social connections as a source of help in times of famine and severe food insecurity (Maxwell et al., 2016). Research on the 2011 famine in Somalia finds that "(t)he nature of reciprocity, the resources available within people's networks, and the collective risks and hazards faced within networks, all determined people's individual and household outcomes in the famine and are related to the social structures and social hierarchies within Somali society" (Maxwell et al., 2016: 63). Those most vulnerable in 2011 were "social groups most dependent on the rural economy with fewest relatives and clan-members outside of these areas (Maxwell et al., 2016: 68).

Intra-household dynamics affect individual household members' access to resources within the household. FAO et al. (2019: 99) note bargaining power is distributed unevenly within households by factors such as gender, age, and birth order. However there is limited evidence and "no systematic bias at the global level has been observed towards one specific age or sex group within a household concerning intra-household food distribution" (FAO et al., 2019: 99). Mbow et al. (2019: 447) reports that intrahousehold food allocation "norms vary according to age, ethnicity, culture, region, and social position, as well as by location in rural or urban areas". Nevertheless, there is a "wide consensus" that because of their weaker bargaining position (underpinned by discriminatory patriarchal norms), within households women and girls "frequently eat least, last and least well" (FAO et al., 2019; 99; Botreau \& Cohen, 2019: 8: Koch \& Fuhrman, 2020: 2). Moreover, "pregnant women tend to receive relatively lower allocations, with likelihood of serious consequences for their own and their child's nutritional status" (FAO et al., 2019: 99). Studies in low- and middle- income countries also report "reduced share of household food resources" to members, including children, with disabilities, with stigma a driving factor (Schwartz et al., 2019: 113; Groce et al., 2014: 311). This rapid review has not found evidence on intra-household food dynamics during famines.

\section{Risks and access}

\section{Risk of malnutrition, morbidity, mortality}

There is some research on malnutrition, morbidity and mortality during famines which provides an insight into the heightened vulnerabilities by age, gender, displacement status and ethnicity (but little evidence was found on the relationship with disability, sexuality and religious identity).

Devereux $(2000: 5,10)$ points out that generalising about patterns of mortality during famines is not easy due to 1) the complexity in estimating mortality estimates and limitations of data; and

2) "complex interactions between biological and sociocultural vulnerability", the latter being context-specific. Devereux (2000: 10) cautions that "(i)ntrahousehold mortality patterns during famines reflect local social hierarchies, cultural practices and economic priorities as well as ageand sex- specific biological vulnerability". With this caveat, key findings on mortality patterns during famines include:

- "Children and young infants are at the greatest risk during famine. In many situations, however, adults and adolescents also die in large numbers. Specialist provision should also be made for these two groups". (Devereux et al., 2017: 12) 
- 'Young children and the elderly are at greatest risk in normal times, and these groups tend to suffer the greatest absolute rise in deaths during food crises" (Devereux, 2000: 10).

Evidence on the risks faced by women, girls and infants include:

- "Although gendered inequalities generally work against women and girls, there is consistent evidence of female mortality advantage (lower death rates for women than men) during famines, for a combination of biological and sociocultural reasons." (Devereux et al., 2017: 11)

- However, in some famines, girls have experienced higher mortality rates than boys. For example, in the Ethiopian famine of the 1970s, while more men than women died overall, there was "evidence of intrahousehold gender bias favouring the survival of sons over daughters", who had mortality rates up to 50 percent higher than boys. (Devereux, 2000: 11)

- "Nutrition is of particular importance for prenatal and/or lactating women and their infants" while at the same time women are "biologically and socially ... more vulnerable to inadequate nutrition during food shortages" (de la O Campus \& Garner, 2014: 7). Women Deliver (2021: 7) highlight that "macro- and micronutrient deficiencies caused by food insecurity and undernutrition among pregnant women can affect pregnancy, nursing, and newborn outcomes and lead to low-weight births, miscarriages, and perinatal mortality". De la O Campus and Garner (2014: 77) note "the first 1000 days between a woman's pregnancy and her child's 2nd birthday are the most essential for protecting lifelong development for babies. For this reason, changes in diet for women and children are of special concern, as micronutrient deficiencies have been associated with heightened morbidity and mortality - particularly among preschool children and pregnant women".

- Some diseases disproportionately affect women in food insecure situations. For example, with limited support or livelihood opportunities, displaced women are more likely to have to sell sex in unsafe situations, leading to risks of HIV or hepatitis B (Taylor-Robinson \& Oleribe, 2016).

The literature highlights that displaced people are often more at risk in famines due to lack of access to food and other resources, poor sanitary conditions, and lack of medical support, while overcrowded refugee camps have often seen the highest mortality rates with the spread of communicable diseases (Devereux, 2000: 5).

Looking at the evidence on minority ethnic groups' risks during famines, Devereux et al. (2017: 12) notes that "during the Somalia famine of 2011, two 'marginal' groups made up the greatest proportion of those who died. The Rahanweyn and Bantu, agro-pastoralists and riverine farmers respectively, have historically lacked power and were the target of looting and violence during the previous Somalia famine". These groups were heavily concentrated in the areas with worst famine conditions as well as comprising the majority of the poorest and the majority of people displaced due to the famine (Devereux et al., 2017: 12). The majority of the deaths of children under five years of age (which accounted for $52 \%$ of total deaths) from the famine occurred within minority groups such as these (Howe, 2018: 153). 
There is evidence of social inequalities affecting the risk of malnutrition (looking specifically at undernutrition and micronutrient deficiencies ${ }^{30}$ ):

- "Women and children living in food-crisis countries are especially vulnerable to malnutrition. In total 7.2 million children suffered from wasting in the 10 worst food crises and 31.9 million suffered from stunting. The highest levels of child wasting were in Yemen, the Sudan and South Sudan, each with a prevalence of around 16 percent. In Yemen, wasting levels reached 31 percent in some governorates. The world's two worst food crises had very high levels of child stunting with 46.4 percent of children under 5 years stunted in Yemen and 42 percent in the Democratic Republic of the Congo" (FSIN \& Global Network Against Food Crises, 2021: 23).

- FAO et al. (2019: 99) finds that "Minority ethnic groups are often at higher risk of different forms of malnutrition. Children in most disadvantaged ethnic groups in low- and lowermiddle-income countries have on average 2.8 times the rate of stunting and six times the rate of wasting compared with their more advantaged peers, although the disparities are much higher in some countries. Additionally, ethnic disparities appear to be increasing in many countries."

- "Widespread and ongoing iron deficiency in women of reproductive age, as well as a higher global malnutrition rate compared with men, reflects systemic discrimination, including within health and nutrition services" (von Grebmer et al., 2020: 26)

- Globally "Children, adolescents and women of childbearing age with disabilities have poorer overall nutritional status than their peers without disabilities" (Holden \& Corby, 2019: 2).

\section{Access to essential services}

Social inequalities and discrimination can impede access to basic services in food secure situations; in food crises these inequalities tend to be exacerbated. Socially constructed barriers that affect access can be environmental, institutional and/or attitudinal. ${ }^{31}$

In food security crisis, people's health and nutritional status weakens, and their needs rise, but basic health care, education, and water and sanitation services may be "damaged, destroyed or closed" due to contexts of protracted poverty, conflict and displacement and other shocks (as found in South Sudan - OCHA, 2021a: 4). "In this type of context, some vulnerable populations face particular barriers to access to services. For example in South Sudan, "(a)pproximately 12 per cent of IDPs and 13 per cent of returnees live in settlements with no access to health

\footnotetext{
30 WHO defines malnutrition as "deficiencies, excesses, or imbalances in a person's intake of energy and/or nutrients" which covers three groups of conditions: 1) "undernutrition, which includes wasting (low weight-forheight), stunting (low height-for-age) and underweight (low weight-for-age)"; 2) "micronutrient-related malnutrition, which includes micronutrient deficiencies (a lack of important vitamins and minerals) or micronutrient excess"; 3 ) "overweight, obesity and diet-related noncommunicable diseases (such as heart disease, stroke, diabetes and some cancers). https://www.who.int/news-room/fact-sheets/detail/malnutrition [Accessed 26 June 2021] This review has not included evidence on micronutrient excess and obesity.

31 This section draws on Carter (2021) which summarises evidence on how social inequalities and discrimination can affect access to essential services in crises.
} 
services", while 2.4 million children were out of school in 2020, mostly girls, with children in rural areas and IDP, refugee and returnee children most vulnerable (OCHA, 2021a: 26)

People with disabilities may be particularly vulnerable in this type of situation (see evidence summary in Carter, 2021: 11-12). Physical, financial and information and communication barriers to access may be particularly problematic for "(p)ersons with multiple disabilities, persons who are blind or partially sighted, deaf and hard of hearing persons, persons with deafblindness, and persons with intellectual and psychosocial disabilities" (Close, 2021: 6), and older persons with disabilities (HNAP, 2019: 7). Research across 28 sites for internally displaced persons displaced by droughts between 2016 and 2018 in Somalia and Somaliland finds women and men with mental health problems, followed by elderly women and men, were reported as most likely to struggle to reach basic services (Fanning, 2018: 14).

\section{Access to humanitarian assistance}

Social inequalities and discrimination can shape access to humanitarian assistance. Humanitarian operations tend "towards one-size-fits-all emergency responses" that do not cater for specific vulnerabilities (Barbelet et al., 2018: 1). The 2016 inter-agency evaluation of the humanitarian response to crisis in the Central African Republic found that the priority to scale up the response meant "too little attention to collection and analysis of [sex and age disaggregated data], and to identification and targeting of specific needs and vulnerabilities. Like most humanitarian responses, the response targeted predefined groups, especially refugees, IDPs and children, and it struggled to target vulnerabilities" (Lawday et al., 2016: 86). As a result "(t)he response systematically underserved people with disabilities, as well as boys and young men, older people, people without families (including widows) and other groups with particular vulnerabilities" (Lawday et al, 2016: 86).

Carter (2021) provides a fuller summary of the evidence on this issue, looking at how vulnerability to exclusion from humanitarian response is driven by 1) discrimination and exclusionary norms and practices; 2 ) limited participatory crisis risk reduction, planning and response; 3 ) invisibility in policy, data, practice and research; 4) capacity and funding constraints.

Here are some examples of the evidence of exclusion, looking in particular at people with disabilities and older people:

- A 2015 global consultation finds that people with disabilities "fall through the cracks" of humanitarian response with three quarters of people with disabilities interviewed reporting to not have "adequate access to basic assistance such as water, shelter, food or health", and half of respondents reporting to not be able to access specialised services such as "rehabilitation, assistive devices, access to social workers or interpreters" (Handicap International, 2015). Cordero et al. (2017: 15) highlight that "Mainstream humanitarian interventions fail to take into account the specific situations of children and adolescents with disabilities. Significant interventions, such as infant and young children feeding programmes, vaccination campaigns and psychosocial support, often reach children through schools, temporary learning spaces and child-friendly spaces, from which children and adolescents with disabilities may be excluded".

- Data on older people is lacking in most humanitarian preparedness and needs assessments and their needs are often overlooked, and particularly in comparison to the 
attention given to women and children in humanitarian response (McGivern, 2020: 14; Barbelet et al., 2018: 23; HelpAge International, 2019). In northeast Nigeria, where food insecurity is driven by conflict and older people face distinct difficulties, older people "described significant challenges in accessing assistance equally. The first problem, voiced by almost every older person interviewed, is that no one speaks with them about their needs and risks" (Amnesty International, 2020: 50).

- Meanwhile, intersecting inequalities can leave people highly vulnerable to exclusion from assistance. For example: a 92-year-old elderly man with disabilities in Somalia reported that in the $\mathbf{2 0 1 6}$ drought he couldn't walk and didn't have money to pay for transport to get to assistance, and so he was left behind in his village, "desperate and hungry" (Lwanga-Ntale \& Owino, 2020: 4). In Somalia, "one-third of households reported that physically disabled women and widows were likely to be excluded from distributions, and $28 \%$ reported that elderly women were", while physically disabled men and elderly men were also at risk of exclusion but to a lesser extent ( $25 \%$ and $22 \%$ respectively) (Fanning, 2018: 14).

Elite capture of aid is a persistent problem in relief efforts (Devereux et al, 2017: 11). For example Devereux et al. (2017: 20) finds that "(i)n Ethiopia in 1984, only one twentieth of the aid went to Tigray (where the rebellion was), despite it having one third of the famine victims. The same was true in Sudan in the later 1980s. At the same time, aid was diverted to government soldiers and to enclaves or populations loyal to governments." Research from Somalia shows that certain clans had less access to humanitarian aid following the 2011-12 famine than others, with aid distribution controlled by dominant clans (Maxwell et al., 2016: 69-70). In another example, Al-Warraq (2019: 8) finds that humanitarian aid to the Muhamasheen community in Yemen "is far less consistent than for other groups, and in some areas the Muhamasheen have been systematically excluded from assistance".

In addition targeting assistance at safe and secure areas can exclude marginalised populations living in more remote areas. For example, the evaluation of the humanitarian response in the Central African Republic found "( $\mathrm{t})$ he response largely failed to assist people in the bush and in host families, partly because their needs were not properly identified or targeted, and partly because of access barriers and insecurity" (Lawday et al., 2016: 85).

\section{Exposure to protection threats related to food crises}

\section{Exclusion, discrimination and deprivation}

Negative coping mechanisms during food crises can have gendered effects with particular risks for women and girls (de la O Campos \& Garner, 2014). For example girls tend to be pulled out of school before boys, while in many societies women and girls shoulder the burden of care, and provide food, water and fuel for their households. Food crises increase these burdens and can expose them to harm and neglect, while the extra work can weaken their immune systems (de la O Campos \& Garner, 2014: 8).

When people leave their homes, some displaced people are particularly vulnerable. For example: 
- OCHA (2021c: 28$)$ highlights that “(w)omen are disproportionately and severely affected by displacement", reporting that "( $\mathrm{m})$ ore than 70 per cent of IDPs in Yemen are women and children, and approximately 30 per cent of displaced households are now headed by females, compared to 9 per cent before conflict escalated in 2015". Humanity \& Inclusion et al. (2021: 5) highlight that "(w)omen's traditional gender roles as caregivers can add additional burdens on women with disabilities, especially in displacement".

- Jimenez-Damary (2020: 6) highlights that internally displaced persons with disabilities with high support needs, "are especially at risk of violence, isolation or neglect ... such as persons with psychosocial or intellectual disabilities, unaccompanied, separated and orphaned children with disabilities or survivors of severe traumatic events".

- In Yemen displaced children can "face problems accessing education and other essential public services" due to a lack of identity documents (OCHA, 2021c: 28).

- On minority groups, OCHA (2021c: 32) finds that in Yemen the many Muhamasheen that have fled their homes as a result of conflict "are less likely to be hosted by local communities due to social prejudice and are therefore more likely to seek shelter on farmland, in public spaces or in other sub-standard living conditions".

\section{Violence, exploitation, abuse and other harm}

Women and girls are particularly vulnerable to various forms of gender-based violence during times of hunger and food insecurity, including through increases in 1) household tensions and domestic violence; 2) exploitation, including engaging in transactional sex; 3 ) risks of sexual exploitation and abuse by aid workers and other food aid distributors; 4) "pressure on families to marry girls at young ages as a coping mechanism to 'protect' girls and sustain families" (Fraser, 2020: 2). The 2021 global review of evidence on sexual exploitation, abuse and sexual harassment in the aid sector highlights that "Aspects of identity combine to increase risks of SEAH [sexual exploitation, abuse and harassment] for particular individuals and groups. Individual factors related to age, gender, sexual orientation, disability, socio-economic status, migrant status, race and ethnicity, issues of isolation create greater risk especially for IDPs, and female headed households" (Feather et al., 2021: 6).

Looking in more detail at the risk of sexual exploitation, abuse and harassment, Fraser (2020: 11) highlights "(s)everal studies have found that women and girls are at increased risk of SEAH to and from food distribution points, as well as cases of aid workers sexually exploiting women and girls in exchange for food assistance". For example, in Syria "women and girls were being sexually exploited by men delivering food aid on behalf of the UN and international charities. ... The scale of the exploitation was so widespread that some Syrian women refused to go to food distribution centres for fear that people would assume they had provided sex in exchange for the food aid" (Fraser, 2020, citing the original studies).

Jimenez-Damary (2020: 12-13) reports that persons with disability in humanitarian displaced settings are at increased risk of "physical, sexual and gender-based violence; robbery, bribery and intimidation and coercion; denial of food and essential medicine, harassment, emotional abuse and neglect, often perpetrated by persons known to them". Particularly vulnerable are "Internally displaced children, women and older persons with disabilities, particularly those with intellectual or psychosocial disabilities" who "may face extreme isolation and marginalization in 
displacement situations" (Jimenez-Damary, 2020: 13). H\&l et al. (2021) find that "(w)omen and girls with disabilities are disproportionately affected by conflict-related sexual violence".

Minority groups may be at risk of violence during times of conflict and severe food insecurity. In Yemen, "( $r$ )eports of violence targeting the Muhamasheen, including [gender-based violence], ... are common" (OCHA, 2021c: 32).

Assessments highlight the vulnerability of children to a range of protection threats, and in particular children with disabilities. For example, WFP (2015b: 56) found in 2015 in South Sudan "displaced children are particularly vulnerable to the psychosocial stress, family separation, physical and sexual violence and recruitment into armed groups. Children (and others) living with disabilities face worsened and specific risks in relation to these and other shocks". When food insecurity and conflict combine, assessments note the risk to boys (and men), or to children in general, of forced recruitment into armed forces or armed groups (in Somalia - Fanning, 2018: 10; in Nigeria - Global Protection Cluster, 2017: 6). Children are also vulnerable to psychosocial harm - found to be "extremely pervasive" among children in North East Nigeria in 2019 (Singh, 2019: 5). Affected children showed high levels of anxiety and outbreaks of anger and aggression, and suffered from nightmares, insomnia and flashbacks (Singh, 2019: 5). This assessment also highlighted the "widespread and pervasive" stigma of children who had been abducted, and particularly "for adolescent girls who had had a child as a result of sexual abuse during captivity" (Singh, 2019: 6).

\section{Measures}

There are a wide range of measures addressing the ways in which social inequalities and discrimination contribute to vulnerability to food insecurity and famine risk. It is beyond the scope of this review to provide a comprehensive mapping. This is an illustrative selection of the type of measures deployed with examples of lessons learned and recommendations in the literature.

\section{Food crisis monitoring and analysis}

Humanitarian organisations are developing tools to monitor vulnerabilities specific to certain subgroup, or disproportionately affecting certain subgroups. HelpAge has "used its Rapid Assessment Method for Older People (RAM-OP) to provide critical information on the malnutrition rate among older people" (Barbelet et al., 2018: 25). The World Food Programme's Gender Equality for Food Security (GE4FS) measure has been tested in 17 countries. It links data on gender and food security with empowerment measures to show how vulnerability is gendered (WFP Gender Office, 2020). The IPC's 2018-22 strategy document states that two additional thematic areas will be added to IPC tools and procedures, to be chosen from: urban areas; gender sensitive analysis; refugees and internally displaced populations; trend analysis; integration with resilience analysis; detailed analysis of contributing factors; expanded analysis of selected populations (IPC, 2019: 13).

Recommendations in the literature include:

- More disaggregated data on population sub-groups would provide a more detailed picture of vulnerability. It is widely agreed that careful analysis of who is likely to be most 
vulnerable to the effects of famine should inform targeting of pre-famine interventions and humanitarian relief (Devereux et al., 2017, p. 12).

- While humanitarian organisations need to include more vulnerability categories in their funding and analysis, with the large number of potentially vulnerable subgroups there is potential for a fragmentation of analysis, and perfunctory exercises (Barbelet et al., 2018: 30). One recommendation is for a holistic, integrated analysis that looks across all vulnerability categories, rather than separate long lists of individual vulnerable groups (Barbelet et al., 2018: 30).

- Humanitarian vulnerability assessments should move from "static" categories based on fixed characteristics of fixed, 'innate and individual' characteristics of population subgroups, such as women, children, persons with disabilities, older persons. The vulnerability of these population sub-groups will vary from context to context and over time (Rao et al., 2020). Researchers therefore emphasise the importance of a "political economy analysis of needs and vulnerability": understanding the socio-economic and political context, the dynamics of the famine, and the causes of vulnerability in order to better address it (Barbelet \& Wake, 2020: 23-25).

- Monitoring should include analysis of social connections: 'the way social networks function in extremis is qualitatively different from the way they function under more "normal" circumstances-and the monitoring of these changes could be a very important kind of information for early warning and response (Maxwell et al., 2016: 72).

\section{Financing and delivery of humanitarian assistance and crisis preparedness}

Devereux et al. (2017) sets out general recommendations for improving humanitarian response to famines, including: improving the timeliness of response; respond to the health causes of famine mortality; and rather than setting up camps, reduce the necessity for people to migrate in search of food by scaling up social protection, water and sanitation facilities, food aid and immunisation campaigns in villages etc. These measures would help all those in famines and severe food crises including those affected by social inequalities.

\section{Humanitarian guidelines set out how responses to famines and food crises should be} targeted and tailored to address specific risks and barriers relating to inequalities. To look more closely at one example, the IASC (2019) Guidelines on Inclusion of Persons with Disabilities in Humanitarian Action set out how it is important when designing food and nutrition programming in crises to understand first what barriers people with disabilities face. IASC (2019: 95) provides a detailed list of potential barriers and appropriate inclusive response. The guidance highlights that "(i)t is also important to recognize that persons with the same impairment may experience barriers differently, for many reasons including their sex, age, culture or socioeconomic status. The complex forms and character of multiple and intersecting discrimination and disability require a multi-criteria risk assessment" (IASC, 2019: 12). The overall recommended approach is "twin-track", combining "inclusive mainstream programmes with targeted interventions for persons with disabilities" (IASC, 2019: 95). The guidance highlights the importance of "inclusive budgeting" which "occurs when an organization, during its planning process, allocates funds to remove barriers and promote participation for persons with disabilities, and to provide targeted activities for persons with disabilities. Inclusive budgets should include costs for improving physical accessibility, providing reasonable accommodations, 
and providing specialized non-food items (NFIs), assistive devices, mobility equipment and accessible communications" (IASC, 2019: 10).

In addressing elite capture of humanitarian aid, Devereux et al. (2017: 12) find "(c)ommunitybased targeting is one way of attempting to ensure that marginalised groups are not excluded, as this approach typically contains a significant element of participation and transparency. However, dominant groups can still manipulate the process". A rapid evaluation of the UK's Department for International Development's (DFID) response to drought in Somalia in 2017 offers several recommendation on how to overcome targeting problems arising from marginalisation, given the experience of aid not reaching "poorly connected" clans (DuBois et al., 2018). Recommendations include having people on the ground who know the context; stronger political, economic and social analysis of the dynamics of marginalisation and exclusion; and identifying "partners and staff coming from those marginalised communities" (DuBois et al., 2018: 27).

\section{Civil society engagement and accountability to affected populations}

Accountability to affected populations (AAP) is a phrase "widely used in the humanitarian community to refer to the commitments and mechanisms that humanitarian agencies have put in place to ensure that communities are meaningfully and continuously involved in decisions that directly impact their lives". ${ }^{32}$ This rapid review provides a brief summary of the evidence and findings available on three issues: 1) women's participation and leadership; 2) measures to address sexual exploitation and abuse within the humanitarian system; and 3) the roles of organisations of people with disabilities and older people's associations in humanitarian crises.

Looking at the evidence on measures supporting women's participation and leadership in famine and food crisis prevention and response, "( $r$ )esearch shows that when women are involved in prevention and crisis response, it leads to better humanitarian outcomes", including "improved food access and food security, particularly among women and children" (Lafrenière et al., 2019: 187, Barclay, 2016: 11 citing findings from UN Women, 201533). However, while there are "many promising efforts underway, these insights are not yet translating into widespread sustained change on the ground", with women's leadership roles as "early responders and promoters of community resilience ... still not fully acknowledged or utilised", and chronic underfunding of gender equality programming (Lafrenière et al., 2019, 188).

Barclay et al. (2016) undertook research into the barriers and opportunities for women's leadership in humanitarian response as identified by women from Bangladesh, Ethiopia, Nepal, occupied Palestinian territory (Gaza), the Philippines and Vanuatu. In the case study of Ethiopia, which was experiencing a severe drought and mass water and food shortages, women's groups were "a key enabling factor for women's leadership in humanitarian action": "the women's savings and credit cooperative provided loans to people outside of the cooperative who were severely affected, sick and most vulnerable to the drought" (Barclay et al., 2016: 27). Women identified "their lack of education, literacy and the burden of unpaid work as the most significant

\footnotetext{
32 https://emergency.unhcr.org/entry/42554/accountability-to-affected-people-aap [Accessed 18 June 2021]

33 UN Women (2015) measured the effect of gender equality programmes on humanitarian outcomes in Nepal, Kenya (Turkana and Dadaab) and the Philippines.
} 
factors hindering their leadership", while the process of limiting participation in the local disaster preparedness committee to members of the (male-dominated) local administration effectively excluded women (Barclay et al., 2016: 14, 34). Across all the contexts, "patriarchal gender norms and cultural practices were a significant barrier to women's leadership" (Barclay et al., 2016: 23).

The Inter-Agency Standing Committee (IASC) Task Force on Accountability to Affected Populations (AAP) is combined with Protection from Sexual Exploitation and Abuse (PSEA), and aims to "foster a culture of accountability and protection from sexual exploitation and abuse at all levels of the humanitarian system". ${ }^{34}$ The 2021 global evidence review on sexual exploitation, abuse and sexual harassment in the aid sector found "a lack of standardisation of what constitutes an effective approach which limits any scope for comparisons across studies" (Feather et al., 2021: 6). The review identified good practice factors such as "managers' awareness of SEAH, a speak-up culture and diversity in the workforce", inclusive and participatory training involving senior leadership and follow-up; and listening to survivors' voices and providing feedback on the process with face-to-face reporting (Feather et al., 2021: 6-7).

There is also growing evidence of the valuable role of organisations of people with disabilities and older people's associations in humanitarian crises, including famines and food insecurity. For example, Palmer (2019) shows from humanitarian responses around the world that inclusion of persons with disabilities and organisations of persons with disabilities in humanitarian planning and response can create a better understanding of potential vulnerabilities and barriers, and improve resilience, among other outcomes. However, this is still an underfunded and under-researched area. An evidence gap mapping (Robinson et al., 2020: unpaginated) found little evidence "on the meaningful participation of people with disability in humanitarian response, inclusive mechanisms for feedback and complaints by people with disability, and coordination of inclusive humanitarian assistance respectively", and none for older people. Looking at organisations of women with disabilities, Sherwood and Pearce (2016) find that their expertise "remains largely untapped in humanitarian crises and they often lack funding and organisational capacity, as well as facing exclusion from both the disability and women's rights movements" (as summarised in Rohwerder, 2017: 13).

\section{Diplomacy relating to conflict prevention, respect for International Humanitarian Law (IHL), and humanitarian access}

The evidence included in this rapid review highlights close links between famine, food insecurity and conflict. One measure to address social inequalities and discrimination in conflict situations is for more inclusive peace processes. UN Security Council Resolution (UNSCR) 1325 (2000) called for more engagement from women in peace processes and conflict resolution. ${ }^{35}$ Krause et al (2018: 1005) find from peace agreements between 1975 and 2011 that those involving women led to "better accord content, higher agreement implementation rates, and longer lasting peace". Research presented by Conciliation Resources shows how inclusion of women, young people, indigenous people and others is beneficial for peace processes, particularly for conflicts based partly or wholly on identity, and recommend various ways to facilitate such inclusion (Carl, 2019).

\footnotetext{
${ }^{34}$ https://interagencystandingcommittee.org/iasc-task-team-on-accountability-to-affected-populations-andprotection-from-sexual-exploitation-and-abuse-aap-psea [Accessed 18 June 2021]

${ }^{35}$ http://unscr.com/en/resolutions/doc/1325 [Accessed 24 June 2021]
} 
However, Humanity \& Inclusion et al.'s (2021: 2) submission on the twentieth anniversary of the UNSCR 1325 highlights that progress has been slow, with women only accounting for, on average between 1992-2019, "13 percent of negotiators, 6 percent of mediators, and 6 percent of signatories in major peace processes worldwide". Moreover, "(w)omen and girls with disabilities are disproportionately impacted by armed conflicts, yet remain underreported and excluded from peace and security processes" despite their "unique experiences, perspectives, and expertise they bring to conflict prevention, response, and the peace table" (H\&l et al., 2021: 2-3).

\section{Evidence from previous food security crises suggests investment in strategic engagement and} diplomacy can support humanitarian response aiming to support vulnerable populations.

Analysis explores how from 2002 "a partnership between donors, agencies and local stakeholders, based on principles of engagement, resulted in coordinated efforts to address the key determinants of the conflict and food insecurity" 36 on the Nuba Mountains population during the Sudanese civil war. Pantuliano (2008: 56) highlights the focus of Nuba Mountains Programme Advancing Conflict Transformation (NMPACT) on principles of engagement, "political humanitarianism", national ownership, inter-agency coordination, and "participatory development as related to programme design and decision making and collective advocacy". These factors were seen as key in formulating "an approach focused on capacity building, promotion of sustainable agriculture and market revitalization alongside conflict transformation and peace building" (Pantuliano, 2008: 56-57). An adequately staffed coordination structure was key, as way learning lessons to help plan for the medium and long-term (such as research work on land tenure issues) while the crisis was still ongoing (Pantuliano, 2008: 57).

\section{Resilience}

Given the trend of protracted, recurrent crises, rising chronic food insecurity and household asset erosion, the humanitarian system has turned to "a greater focus on increasing resilience to shocks" (O'Brien, 2017: 13). Today, at least at the level of research and policy, definition of resilience in international development "has expanded beyond the idea of 'coping' with shocks and stressors and now includes a focus on improvement in well-being and consideration of the factors that may inhibit well-being due to social, political or economic exclusion" (Bene et al., 2019: vi). Given the limitations of this rapid review, this section provides some brief highlights of the evidence on two key resilience approaches in the context of famine and food insecurity: social protection and women's empowerment.

Social protection is a key approach used today "to provide regular and predictable transfers to people in a situation of chronic or seasonal food insecurity", and in this way "strengthen resilience and protect the livelihoods of the most vulnerable households” (O'Brien, 2017: 13). Shock-responsive social protection programmes is a key approach to linking humanitarian relief to development, with the intention of linking these programmes to early warning mechanisms so that they can be expanded before, or immediately after a crisis (Devereux, 2021: 12-13; WinderRossi et al, 2017: 7). Expansion of social assistance (non-contributory social protection) - and in particular cash transfers - has been a common response taken by governments to mitigate the economic impacts of COVID-19, especially for informal urban workers vulnerable to sudden job losses (Gentilini et al, 2021). There is growing awareness of the need to make such social

\footnotetext{
${ }^{36}$ https://odi.org/en/publications/responding-to-protracted-crises-the-principled-model-of-nmpact-in-sudan/ [Accessed 26 June 2021]
} 
protection inclusive, but coverage remains limited for some people affected by social inequalities. For example, UNPRPD and ILO (2021) detail the low coverage in the case of people with disabilities and their households.

This rapid review found a large literature on improving households' food security through supporting women's empowerment. There is consensus that promoting gender equality, gender-equitable food systems, and women's agency at individual, household and community levels is key to improving food security for women and their households. ${ }^{37}$ Mbow et al. (2019: 448 , citing several studies) find with high confidence "(e)mpowering and valuing women in their societies increases their capacity to improve food security under climate change and make substantial contributions to their own well-being, to that of their families and of their communities". For example, a randomised control trial of a social and economic empowerment programme in South Kivu province in the Democratic Republic of Congo found the intervention increased women's savings, assets and access to credit; their entrepreneurial worth and net earnings; improved their mental health, participation in household in decision-making, social support, and household diet diversity (Noble et al., 2020).

However a review of the evidence finds "little evidence on causal pathways or mechanisms" that support women's empowerment (Njuke et al, 2021: 4-5). A 3ie evidence mapping exercise found "relatively few studies" of "interventions supporting women's decision-making or measured outcomes regarding women's empowerment" (Moore et al., 2021: 34). Existing evidence tends to offer "locally or contextually specific findings" (Njuke et al., 2021: 5). Moreover, there is even less research on addressing the impact of other social inequalities through resilience interventions: a 2020 evidence gap mapping on disability and older people in humanitarian response found a lack of evidence on building resilience and preparedness for people with disability and older people through inclusive humanitarian response (Robinson et al., 2020).

Nevertheless, analyses of the available evidence identify promising approaches. For example, a review of women's economic programming linked with land programming identifies promising approaches as including "engaging both men and women; linking awareness of land rights to wider rights (including related to marriage); and involving women in groups and in local governance mechanisms on land." (Beavor \& Augustinus, 2018: 12). There is also growing awareness "gender norms and structural biases can limit women's influence and voice" with unpaid care work and gender-based violence systematic barriers for women's empowerment in food systems (38; Brody et al., 2014). This requires a shift in focus from the capacity of women to take individual actions in isolation, to gender-transformative approaches that "explore underlying causes of inequality and build consciousness, social capital and solidarity between women and men" (CARE-USA, 2020: 7).

\footnotetext{
${ }^{37}$ https://www.ifpri.org/blog/gender-equality-womens-empowerment-and-food-systems-consensus-and-gapsliterature [Accessed 23 June 2021].

38 https://www.ifpri.org/blog/gender-equality-womens-empowerment-and-food-systems-consensus-and-gapsliterature [Accessed 23 June 2021]
} 


\section{References}

Adger, W. N. (2006). Vulnerability. Global Environmental Change, 16(3), 268-281. https://doi.org/10.1016/j.gloenvcha.2006.02.006

Al-Warraq, A. (2019). The Historic And Systematic Marginalization Of Yemen's Muhamasheen Community. Sana'a Center for Strategic Studies. https://sanaacenter.org/files/Muhamasheen_en.pdf

Amnesty International. (2020). My heart is in pain-Older People's Experience of Conflict, Displacement, and Detention in Northeast Nigeria. Amnesty International. https://www.amnesty.org/en/documents/afr44/3376/2020/en

Bahgat, K., Dupuy, K., Gates, S., Nygård, H. M., Rustad, S. A., Strand, H., Urdal, H., Østby, G., Barrett, G., \& Hillesund, S. (2017). Inequality and armed conflict: Evidence and data. Peace Research Institute Oslo. https://www.prio.org/utility/DownloadFile.ashx?id=954\&type=publicationfile

Barbelet, V., \& Wake, C. (2020). Inclusion and exclusion in humanitarian action. Humanitarian Policy Group. London: Overseas Development Institute. https://cdn.odi.org/media/documents/Inclusion and exclusion in humanitarian action the _state_of_play.pdf

Barbelet, V., Samuels, F., \& Plank, G. (2018). The role and vulnerabilities of older people in drought in East Africa. Overseas Development Institute. https://cdn.odi.org/media/documents/12293.pdf

Barclay, A., Higelin, M., \& Bungcaras, M. (2016). On the frontline: catalysing women's leadership in humanitarian action. Johannesburg: Action Aid. https://www.actionaid.org.uk/sites/default/files/publications/actionaid_policy_report_on_the_fron tline_catalysing_womens_leadership_in_humanitarian_action.pdf

Baro, M., \& Deubel, T. F. (2006). Persistent Hunger: Perspectives on Vulnerability, Famine, and Food Security in Sub-Saharan Africa. Annual Review of Anthropology, 35(1), 521-538. https://doi.org/10.1146/annurev.anthro.35.081705.123224

Beavor, A., \& Augustinus, C. (2018). Women's Economic Empowerment Linked to Land Programming: A Review of evidence for DFID Ethiopia. WOW Helpdesk Query 14 Final Report.

https://assets.publishing.service.gov.uk/government/uploads/system/uploads/attachment_d ata/file/763991/women-econ-empowerment-land-programmimg-Ethiopia.pdf

Bene, T., Robinson, D., Laanouni, F., Bahr Caballero, K., Murphy, B., \& Wilson, D. (2019). Strategic Evaluation of WFP Support for Enhanced Resilience January 2019 Evaluation Report: Volume I. World Food Programme, Office of Evaluation. https://www.itad.com/wpcontent/uploads/2020/02/WFP-enhanced-resilience-1.pdf

Berkhout, E., Galasso, N., Lawson, M., Rivero Morales, P. A., Taneja, A., \& Vázquez Pimentel, D. A. (2021). The Inequality Virus: Bringing together a world torn apart by coronavirus through a fair, just and sustainable economy. Oxfam International. Oxford: Oxfam GB for Oxfam International. https://oxfamilibrary.openrepository.com/bitstream/handle/10546/621149/bp-the-inequalityvirus-250121-en.pdf

Birchall, J. (2019). Gender as a causal factor in conflict. K4D Helpdesk Report 549. Brighton, UK: Institute of Development Studies.

https://opendocs.ids.ac.uk/opendocs/handle/20.500.12413/14393 
Bishop, A. (2020). Vulnerability amplified: the impact of the COVID-19 pandemic on LGBTIQ people. New York: OutRight Action International.

https://outrightinternational.org/sites/default/files/COVIDsReportDesign_FINAL_LR_0.pdf

Botreau, H., \& Cohen, M. (2019). Gender inequalities and food insecurity. Ten years after the food price crisis, why are women farmers still food-insecure? Oxford: Oxfam GB for Oxfam International. https://reliefweb.int/sites/reliefweb.int/files/resources/bp-gender-inequalities-foodinsecurity-150719-en.pdf

Brody, A., Spieldoch, A., \& Aboud, G. (2014). Gender and Food Security. Towards Gender-Just Food and Nutrition Security. Overview Report. Brighton: Institute of Development Studies. https://opendocs.ids.ac.uk/opendocs/bitstream/handle/20.500.12413/5245/IDS_Bridge_Food_S ecurity_Report_Online.pdf

Brottem, L., \& McDonnell, A. (2020). Pastoralism and Conflict in the Sudano-Sahel: A Review of the Literature, 1st ed. Washington DC: Search for Common Ground. https://csfsudan.org/wp-content/uploads/2021/03/pastoralism_and_conflict_in_the_sudanosahel_jul_20201.pdf

CARE. (2021). 'If We Don't Work, We Don't Eat'. Syrian Women Face Mounting Food Insecurity a Decade into the Conflict. Jordan: CARE Middle East and North Africa. https://www.careinternational.org/files/files/CARE_Syria_Food_Security_Report_24_February.pdf

CARE-USA. (2020). Gender Equality and Women's Empowerment in the context of Food Security and Nutrition. A Scoping Paper - September 2020. http://www.fao.org/fileadmin/templates/cfs/Docs1920/Gender/GEWE_Scoping_PaperFINAL040ct.pdf

Carl, A. (ed.) (2019). Inclusion in peace processes. Accord 28, Conciliation Resources, 2019. https://rc-services-assets.s3.eu-west-1.amazonaws.com/s3fspublic/Navigating_inclusion_in_peace_processes_Accord_Issue_28.pdf

Carter, B. (2021). Impact of social inequalities and discrimination on vulnerability to crises. K4D Helpdesk Report 994. Brighton, UK: Institute of Development Studies. https://opendocs.ids.ac.uk/opendocs/handle/20.500.12413/16541

Close, S. (2021). Untapped peacebuilders: Including persons with disabilities in building peace. London: Conciliation Resources. https://www.c-r.org/learning-hub/untapped-peacebuildersincluding-persons-disabilities-building-peace

Cordero, R. P., Mitra, G., \& Tucker, M. (2017). Guidance: Including Children with Disabilities in Humanitarian Action - General. UNICEF.

https://resourcecentre.savethechildren.net/node/13765/pdf/unicef_general_guidance_engli sh.pdf

de la O Campos, A. P., \& Garner, E. (2014). Women's resilience to food price volatility: A policy response. Food and Agriculture Organisation. http://www.fao.org/policy-support/tools-andpublications/resources-details/en/c/1208520/

Devereux, S. (2000). Famine in the Twentieth Century. IDS working papers 105. Brighton, UK: Institute of Development Studies.

https://opendocs.ids.ac.uk/opendocs/bitstream/handle/20.500.12413/3435/wp105.pdf?seq uence $=1$ \&isAllowed $=\mathrm{y}$

Devereux, S. (2006). Distinguishing between chronic and transitory food insecurity in emergency needs assessments. World Food Programme, Emergency Needs Assessment Branch 
(ODAN). http://www.livestock-emergency.net/userfiles/file/assessment-review/InstitueDevelopment-Studies-2006.pdf

Devereux, S. (2009). Why does famine persist in Africa? Food Security, 1. pp. 25-35. https://doi.org/10.1007/s12571-008-0005-8

Devereux, S. (2021). Social protection responses to COVID-19 in Africa. Global Social Policy. June 2021. https://doi.org/10.1177\%2F14680181211021260

Devereux, S., Sida, L., \& Nelis, T. (2017). Famine: Lessons Learned. Humanitarian Learning Centre.

https://opendocs.ids.ac.uk/opendocs/bitstream/handle/20.500.12413/13173/Lessons\%20L earned\%20FINAL\%20online.pdf?sequence=1\&isAllowed=y

DFID. (1999). DFID sustainable livelihoods guidance sheets. Section 1. https://www.ennonline.net/attachments/871/dfid-sustainable-livelihoods-guidance-sheetsection $1 . p d f$

DG ECHO. (2016). Improving protection outcomes to reduce risks for people in humanitarian crises. DG ECHO Thematic Policy Document $n^{\circ} 8$. European Commission DirectorateGeneral for Humanitarian Aid and Civil Protection. https://ec.europa.eu/echo/sites/echosite/files/policy_guidelines_humanitarian_protection_en.pdf

DuBois, M., Harvey, P., \& Taylor, G. (2018). Rapid Real-Time Review DFID Somalia Drought Response.

https://assets.publishing.service.gov.uk/media/5a8566e4e5274a2e87dc3e43/DFID_Somali a_2017_IRF_Real_Time_Review_FINAL.pdf

Elver, H. (2017). Interim report of the Special Rapporteur on the right to food. Seventy-second session Item 73 (b) of the provisional agenda. United Nations General Assembly. https://undocs.org/A/72/188

Elver, H. (2020). Critical perspective on food systems, food crises and the future of the right to food. Report of the Special Rapporteur on the right to food. Human Rights Council Fortythird session 24 February-20 March 2020 Agenda item 3. United Nations General Assembly. https://undocs.org/en/A/HRC/43/44

Fanning, E. (2018). Drought, Displacement and Livelihoods in Somalia/Somaliland: Time for gender-sensitive and protection-focused approaches. Concern Worldwide; Danish Refugee Council; Norwegian Refugee Council; Oxfam; Plan International; REACH; Save Somali Women and Children. https://doi.org/10.21201/2018.2845

FAO. (2018a). Pastoralism in Africa's drylands. Rome. http://www.fao.org/3/ca1312en/CA1312EN.pdf

FAO. (2018b). The gender gap in land rights. Rome: FAO. http://www.fao.org/3/l8796EN/i8796en.pdf

FAO, IFAD, UNICEF, WFP, \& WHO. (2019). The State of Food Security and Nutrition in the World 2019. Safeguarding against economic slowdowns and downturns. Rome, FAO. https://docs.wfp.org/api/documents/WFP0000106760/download/?_ga=2.239053186.306077665.162326752710114967.1618837733

FAO, IFAD, UNICEF, WFP, \& WHO. (2020). The State of Food Security and Nutrition in the World 2020. Transforming food systems for affordable healthy diets. Rome, FAO. https://doi.org/10.4060/ca9692en 
Feather, J., Martin, R., \& Neville, S. (2021). Global Evidence Review of SEAH in the Aid Sector. London, UK: RSH Resource \& Support Hub.

https://safeguardingsupporthub.org/sites/default/files/2021-

03/RSH_Global_Evidence_Review_Final_Design_V5.pdf

FEWS NET. (2018). Integrating Acute Malnutrition and Mortality into Scenario Development. Washington, DC: FEWS NET.

https://fews.net/sites/default/files/documents/reports/Guidance_Document_Malnutrition_20 18.pdf

Fraser, E. (2020). Food Security, VAWG and Nutrition, VAWG Helpdesk Research Report No. 309. London, UK: VAWG Helpdesk. https://www.sddirect.org.uk/media/1881/vawghelpdesk-284-covid-19-and-vawg.pdf

FSIN \& Global Network Against Food Crises. (2021). Global Report on Food Crises 2021. Rome. https://www.fsinplatform.org/sites/default/files/resources/files/GRFC\%202021\%20050521 $\% 20$ med.pdf

Gentilini, U., Almenfi, M., Blomquist, J., Dale, P., De la Flor Giuffra, L., Desai, V., Belen Fontenez, M., Galicia, G., Lopez, V., Marin, G., Mujica, I. V., Natarajan, H., Newhouse, D., Palacios, R., Quiroz, A. P., Rodriguez Alas, C., Sabharwal, G., \& Weber, M. (2021). Social Protection and Jobs Responses to COVID-19: A Real-Time Review of Country Measures. "Living paper" version 15 (May 14, 2021). Washington, DC.: World Bank. https://openknowledge.worldbank.org/handle/10986/33635

Global Protection Cluster. (2017). Nigeria, South Sudan, Somalia and Yemen are facing famine or a credible risk of famine.

https://reliefweb.int/sites/reliefweb.int/files/resources/gpc_briefing-note_four-famines.pdf

Groce, N., Challenger, E., Berman-Bieler, R., Farkas, A., Yilmaz, N., Schultink, W., ... \& Kerac, M. (2014). Malnutrition and disability: unexplored opportunities for collaboration. Paediatrics and international child health, 34(4), 308-314.

https://dx.doi.org/10.1179\%2F2046905514Y.0000000156

Handicap International. (2015). Disability in humanitarian context. Views from affected people and field organisations.

https://reliefweb.int/sites/reliefweb.int/files/resources/_Handicap_International_Disability_i n_humanitarian_context.pdf

HelpAge International. (2019). More at risk: How older people are excluded in humanitarian data. HelpAge International. https://ageingasia.org/how-older-people-are-excluded-inhumanitarian-data/

Hendriks, S.L. (2015). The food security continuum: a novel tool for understanding food insecurity as a range of experiences. Food Sec. 7, 609-619 (2015). https://doi.org/10.1007/s12571-015-0457-6

HNAP. (2019). Disability: prevalence and impact. A Nationwide Household Survey Using Washington Group Methodology. Humanitarian Needs Assessment Programme. https://www.globalprotectioncluster.org/wp-content/uploads/Disability_Prevalence-andImpact_FINAL-2.pdf

Holden, J., \& Corby, N. (2019). Nutrition programming for people with disabilities: evidence and learning. Disability Inclusion Helpdesk Research Report No. 6. London, UK: Disability Inclusion Helpdesk. 
https://assets.publishing.service.gov.uk/government/uploads/system/uploads/attachment_d ata/file/818123/query-6-disability-and-nutrition.pdf

House, C. (2020). Out of the Margins: LBT+ exclusion through the lens of the SDGs. Report on key research findings from the global Out of the Margins network. Stonewall. https://outofthemargins.org.uk/wp-content/uploads/2020/05/Out-of-the-Margins-report2020.pdf

Howe, P. (2018). Famine systems: A new model for understanding the development of famines, World Development 105 (2018) pp. 144-155.

https://doi.org/10.1016/j.worlddev.2017.12.028

Howe, P., \& Devereux, S. (2004). Famine intensity and magnitude scales: a proposal for an instrumental definition of famine. Disasters, 28(4), 353-372. https://doi.org/10.1111/j.03613666.2004.00263.x

Human Rights Council. (2020). "There is nothing left for us": starvation as a method of warfare in South Sudan. Conference room paper of the Commission on Human Rights in South Sudan.

https://www.ohchr.org/EN/HRBodies/HRC/RegularSessions/Session45/Documents/A_HR C_45_CRP.3.docx

Humanity \& Inclusion, Human Rights Watch, International Disability Alliance, Women Enabled International \& Women's Refugee Commission. (2021). Joint submission on promoting and protecting the human rights of women and girls in conflict and post-conflict situations on the occasion of the twentieth anniversary of Security Council resolution 1325.

https://www.internationaldisabilityalliance.org/sites/default/files/joint_ohchr_submission_fin al_2_april_2021.pdf

IASC. (2019). Guidelines. Inclusion Of Persons With Disabilities In Humanitarian Action. IASC Task Team on inclusion of Persons with Disabilities in Humanitarian Action. Inter Agency Standing Committee. https://interagencystandingcommittee.org/system/files/202011/IASC\%20Guidelines\%20on\%20the\%20Inclusion\%20of\%20Persons\%20with\%20Disabil ities\%20in\%20Humanitarian\%20Action\%2C\%202019_0.pdf

ILGA World. (2020). The Impact of COVID-19 on the Human Rights of LGBT Persons, Communities and/or Populations. Submission to the Independent Expert on protection against violence and discrimination based on sexual orientation and gender identity. International Lesbian, Gay, Bisexual, Trans and Intersex Association https://www.ohchr.org/Documents/Issues/SexualOrientation/IESOGI-COVID19/CSOs/ILGA-World.docx

International Development Association. (2020). Responding to the Emerging Food Security Crisis (English). Washington, D.C.: World Bank Group.

https://documents1.worldbank.org/curated/en/775981606955884100/pdf/Responding-tothe-Emerging-Food-Security-Crisis.pdf

IPC. (2020). The IPC famine fact sheet. Integrated Food Security Phase Classification. https://reliefweb.int/sites/reliefweb.int/files/resources/IPC_Famine_Factsheet_2020Nov_0. pdf

IPC. (2021). Ethiopia. IPC Acute Food Insecurity Analysis May - September 2021. Issued June 2021. Integrated Food Security Phase Classification.

https://reliefweb.int/sites/reliefweb.int/files/resources/IPC_Ethiopia_Acute_Food_Insecurity _2021MaySept_national.pdf 
IPC Global Partners. (2019). Integrated Food Security Phase Classification Technical Manual Version 3.0. Evidence and Standards for Better Food Security and Nutrition Decisions. Rome.

http://www.ipcinfo.org/fileadmin/user_upload/ipcinfo/manual/IPC_Technical_Manual_3_Fin al.pdf

Jimenez-Damary, C. (2020). Persons with disabilities in the context of internal displacement. Report of the Special Rapporteur on the human rights of internally displaced persons. https://undocs.org/A/HRC/44/41

Jobbins, M., \& McDonnell, A. (2021). Pastoralism and Conflict: Tools for Prevention and Response in the Sudano-Sahel, 1st ed. Washington DC: Search for Common Ground. https://www.dmeforpeace.org/pastoralism-conflict-toolkit/wpcontent/uploads/2021/03/Pastoralism-and-Conflict-Toolkit-Search-for-Common-Ground2021.pdf

Josephson, A., Kilic, T., \& Michler, J.D. (2020). Socioeconomic Impacts of COVID-19 in Four African Countries. Policy Research Working Paper No. 9466. Washington, DC: World Bank. https://openknowledge.worldbank.org/handle/10986/34733

Juergens, F., \& Galvani, F. (2021). Social protection for older people during COVID-19 and beyond. SPACE Social Protection Approaches to COVID-19: Expert advice helpline, and HelpAge International. Published by DFID and GIZ.

https://socialprotection.org/sites/default/files/publications_files/Social\%20protection\%20for \%20older\%20people\%20during\%20COVID-19.pdf

Kim, J. J., McCloskey, E., Hailey, P., \& Maxwell, D. (2018). Constraints and Complexities of Information and Analysis: Data Planning in Famine-Risk Countries Findings and recommendations for food security analysis: South Sudan, Somalia, Nigeria and Yemen. MQSUN+. https://fic.tufts.edu/wp-content/uploads/MQSUN-Final-Report.pdf

Koch, R., \& Fuhrman, S. (2020). Sometimes we don't even eat: How Conflict and COVID-19 Are Pushing Millions of People to the Brink. CARE. https://insights.careinternational.org.uk/media/k2/attachments/CARE_Sometimes-we-donteven-eat_report_Nov-2020.pdf

Krause, J., Krause, W., \& Bränfors, P. (2018). Women's participation in peace negotiations and the durability of peace. International Interactions, 44(6), 985-1016. https://doi.org/10.1080/03050629.2018.1492386

Kuran, C. H. A., Morsut, C., Kruke, B. I., Krüger, M., Segnestam, L., Orru, K., ... \& Torpan, S. (2020). Vulnerability and vulnerable groups from an intersectionality perspective. International Journal of Disaster Risk Reduction, 50, 101826. https://doi.org/10.1016/j.ijdrr.2020.101826

Lafrenière, J., Sweetman, S., \& Thylin, T. (2019). Introduction: gender, humanitarian action and crisis response, Gender \& Development, 27:2, 187-201.

https://doi.org/10.1080/13552074.2019.1634332

Lautze, S., Stites, E., Nojumi, N., \& Najimi, F. (2002). Qaht-E-Pool "A Cash Famine": Food Insecurity In Afghanistan 1999 - 2002. Feinstein International Center.

https://reliefweb.int/sites/reliefweb.int/files/resources/9267090F31843C2B85256BD400573 1B6-tufts-afg-07june.pdf

Lawday, A., Adjibade, K., Dahrendorf, N., Kubwayezu, F., \& Morinière, L.C. (2016). Inter-Agency Humanitarian Evaluation of the Response to the Crisis in the Central African Republic. Report Commissioned by the Steering Group for Inter-Agency Humanitarian Evaluations, New York, March 2016. 
https://www.humanitarianresponse.info/sites/www.humanitarianresponse.info/files/2019/08 /IAHE---CAR-Crisis---2016.pdf

Levine, S., \& Sharp, K. (2015). Topic Guide: Anticipating and responding to shocks: livelihoods and humanitarian responses. Evidence on Demand. Overseas Development Institute. http://dx.doi.org/10.12774/eod_tg.november2015.levineandsharp

Lwanga-Ntale, C., \& Owino, B.O. (2020). Understanding vulnerability and resilience in Somalia. Jàmbá: Journal of Disaster Risk Studies 12(1), a856. https://doi.org/ 10.4102/jamba.v12i1.856

Madrigal-Borloz, V. (2018). Report of the Independent Expert on protection against violence and discrimination based on sexual orientation and gender identity. Human Rights Council Thirty-eighth session 18 June-6 July 2018 Agenda item 3. United Nations. https://undocs.org/pdf?symbol=en/A/HRC/38/43

Marin-Ferrer, M., Vernaccini, L., \& Poljansek, K. (2017). Index for Risk Management INFORM Concept and Methodology Report - Version 2017. EUR 28655 EN. https://doi.org/10.2760/094023

Maxwell, D. (2019). Famine Early Warning and Information Systems in Conflict Settings: Challenges for Humanitarian Metrics and Response. London School of Economics. http://eprints.Ise.ac.uk/102836/1/Maxwell_famine_early_warning_and_information_system s_published.pdf

Maxwell, D., \& Hailey, P. (2020). The Politics of Information and Analysis in Famines and Extreme Emergencies: Synthesis of Findings from Six Case Studies. Boston: Feinstein International Center, Tufts University. https://assets.publishing.service.gov.uk/media/5ec2902ce90e071e28843664/PIA_Synthesi s_Report_May_13.pdf

Maxwell, D., Hailey, P., Baker, L. S., \& Kim, J. J. (2019). Constraints and Complexities of Information and Analysis in Humanitarian Emergencies: Evidence from Yemen. Boston: Feinstein International Center, Tufts University. https://fic.tufts.edu/wpcontent/uploads/2019-Evidence-from-Yemen-final.pdf

Maxwell, D., Hailey, P., Kim, J. J., McCloskey, E., \& Wrabel, M. (2018). Constraints and complexities of information and analysis in humanitarian emergencies: Evidence from South Sudan. Feinstein International Center. https://fic.tufts.edu/wpcontent/uploads/SouthSudan-Case-Study-Report.pdf

Maxwell, D., Majid, N., Adan, G., Abdirahman, K., \& Kim, J. J. (2016). Facing famine: Somali experiences in the famine of 2011. Food Policy, 65, 63-73. https://doi.org/10.1016/j.foodpol.2016.11.001

Mbow, C., Rosenzweig, C., Barioni, L. G., Benton, T. G., Herrero, M., Krishnapillai, M., Liwenga, E., Pradhan, P., Rivera-Ferre, M. G., Sapkota, T.., Tubiello, F. N., \& Xu, Y. (2019). Food Security. In: Climate Change and Land: an IPCC special report on climate change, desertification, land degradation, sustainable land management, food security, and greenhouse gas fluxes in terrestrial ecosystems [P.R. Shukla, J. Skea, E. Calvo Buendia, V. Masson-Delmotte, H.-O. Pörtner, D.C. Roberts, P. Zhai, R. Slade, S. Connors, R. van Diemen, M. Ferrat, E. Haughey, S. Luz, S. Neogi, M. Pathak, J. Petzold, J. Portugal Pereira, P. Vyas, E. Huntley, K. Kissick, M. Belkacemi, J. Malley, (eds.)]. In press. https://www.ipcc.ch/site/assets/uploads/sites/4/2021/02/08_Chapter-5_3.pdf 
McGivern, V. (2020). If not now, when? Keeping promises to older people affected by humanitarian crises. HelpAge International.

https://reliefweb.int/sites/reliefweb.int/files/resources/lf-not-now-when-Report.pdf

Meaney-Davis, J. (2020). The financial and economic impacts of the COVID-19 pandemic on people with disabilities in low- and middle-income countries. Disability Inclusion Helpdesk Research Report No. 42. London, UK: Disability Inclusion Helpdesk. https://www.sddirect.org.uk/media/2063/query-no-42-economic-impacts-of-covid-19.pdf

Messer, E., \& Cohen, M. J. (2004). Breaking the links between conflict and hunger in Africa. 2020 Africa Conference Brief 10. Washington D.C.: International Food Policy Research Institute. https://core.ac.uk/download/pdf/6289278.pdf

Moore, N., Lane, C., Storhaug, I., Franich, A., Rolker, H., Furgeson, J., Sparling, T., \& Snilstveit, B. (2021). The effects of food systems interventions on food security and nutrition outcomes in low- and middle-income countries, 3ie Evidence Gap Map Report 16. New Delhi: International Initiative for Impact Evaluation (3ie). https://doi.org/10.23846/EGM016

Njuki, J., Eissler, S., Malapit, H., Meinzen-Dick, R., Bryan, E., \& Quisumbing, A. (2021). A review of evidence on gender equality, women's empowerment, and food systems. Food Systems Summit Brief Prepared by Research Partners of the Scientific Group for the Food Systems Summit, May 11th 2021. https://sc-fss2021.org/wp-

content/uploads/2021/06/FSS_Brief_gender_equality.pdf

Noble, E., Ascencio, L., Wilondja, T., Mateba, A., Angelucci, M., Heath, R. (2020). The Impact of Women for Women International's Economic and Social Empowerment Program in the Democratic Republic of Congo. Washington DC: Women for Women International. https://www.womenforwomen.org/sites/default/files/2021-02/DRC8pger.pdf

O'Brien, C., Cherrier, C., Watson, C., \& Congrave, J. (2017). Shock-Responsive Social Protection Systems Research: Case study—Regional approaches to addressing food insecurity in the Sahel, and the contribution of social protection. Oxford, UK: Oxford Policy Management. https://www.opml.co.uk/files/Publications/a0408-shock-responsive-socialprotection-systems/opm-case-study-2017-srsp-sahel.pdf?noredirect=1

OCHA. (2021a). Humanitarian Needs Overview. South Sudan. Issued January 2021. United Nations Office for the Coordination of Humanitarian Affairs.

https://reliefweb.int/sites/reliefweb.int/files/resources/south_sudan_2021_humanitarian_ne eds_overview.pdf

OCHA. (2021b). Humanitarian Needs Overview. Syrian Arab Republic. Issued March 2021. United Nations Office for the Coordination of Humanitarian Affairs.

https://reliefweb.int/sites/reliefweb.int/files/resources/syria_2021_humanitarian_needs_ove rview.pdf

OCHA. (2021c). Humanitarian Needs Overview 2021. Yemen. Issued February 2021. https://reliefweb.int/sites/reliefweb.int/files/resources/Yemen_HNO_2021_Final.pdf

Palmer, T. (2019). Inclusion of persons with disabilities in humanitarian action: 39 examples of field practices, and learning from 20 countries, for all phases of humanitarian response. https://reliefweb.int/sites/reliefweb.int/files/resources/Case\%20studies_Inclusion\%20of\%20 persons\%20with\%20disabilities\%20in\%20humanitarian\%20action_CBM_HI_IDA.pdf

Pantuliano, S. (2008). Responding to protracted crises: The principled model of NMPACT in Sudan. In Alinovi, L., Hemrich, G. \& Russo, L. (Eds.) Beyond Relief: Food Security in 
Protracted Crises (pp. 25-64). FAO. Practical Action Publishing. http://www.fao.org/3/a0778e/a0778e00.pdf

Pavanello, S. (2009). Pastoralists' vulnerability in the Horn of Africa: Exploring political marginalisation, donors' policies and cross-border issues-Literature review. Humanitarian Policy Group, Overseas Development Institute, London.

https://www.preventionweb.net/files/24285_24285literaturereviewrread1.pdf

Peacocke, P., Watson, S., Turrall, S., Walker, D., Kabuchu, H., Bahr Caballero, K., \& Sørensen, P. (2020). Evaluation of the Gender Policy (2015-2020) Evaluation Report: Volume I. Commissioned by the WFP Office of Evaluation. https://docs.wfp.org/api/documents/WFP0000116033/download/?_ga=2.226417817.2036097864.1611064610358218219.1607357985

Rao, N., Mishra, A., Prakash, A., Singh, C., Qaisrani, A., Poonacha, P., ... \& Bedelian, C. (2019). A qualitative comparative analysis of women's agency and adaptive capacity in climate change hotspots in Asia and Africa. Nature Climate Change, 9(12), 964-971. https://doi.org/10.1038/s41558-019-0638-y

Rao, N., Singh, C., Solomon, D., Camfield, L., Sidiki, R., Angula, M., Poonacha, P., Sidibé, A., \& Lawson, E. T. (2020). Managing risk, changing aspirations and household dynamics: Implications for wellbeing and adaptation in semi-arid Africa and India. World Development, 125, 104667. https://doi.org/10.1016/j.worlddev.2019.104667

Rivers, J. P., Holt, J. F. J., Seaman, J. A., \& Bowden, M. R. (1976). Lessons for epidemiology from the Ethiopian famines. Ann Soc Belg Med Trop, 56(4-5), 345-360. http://lib.itg.be/open/ASBMT/1976/1976asbm0345.pdf

Robinson, A., Marella, M., \& Logan, L., (2020). Gap analysis on the inclusion of people with disability and older people in humanitarian response. ELRHA. https://www.elrha.org/wpcontent/uploads/2020/07/EIrha-HIF_Gap-Analysis_Inclusion-of-people-with-disability-andolder-people_Literature-Review2020-A.pdf

Rohwerder, B. (2017). Disability Inclusive Humanitarian Response: Operational Practice Paper 1. Brighton: Institute of Development Studies.

https://opendocs.ids.ac.uk/opendocs/bitstream/handle/20.500.12413/13404/HLC\%20OPP 1. pdf? sequence $=1$ \&isAllowed $=y$

Rohwerder, B. (2020). Social impacts and responses related to COVID-19 in low- and middleincome countries. K4D Emerging Issues Report 35. Brighton, UK: Institute of Development Studies.

https://opendocs.ids.ac.uk/opendocs/bitstream/handle/20.500.12413/15625/Emerging\%20I ssues\%20report_Covid-

19\%20and\%20Social\%20Development_FINAL_24.9.2020\%20edits.pdf?sequence=5\&isAll owed $=y$

Schwartz, N., Buliung, R., \& Wilson, K. (2019). Disability and food access and insecurity: A scoping review of the literature. Health \& place, 57, 107-121.

https://doi.org/10.1016/j.healthplace.2019.03.011

Sherwood, E., \& Pearce, E. (2016). "Working to Improve Our Own Futures": Inclusion of Women and Girls with Disabilities in Humanitarian Action. Women's Refugee Commission. https://www.womensrefugeecommission.org/wp-content/uploads/2020/04/StrengtheningNetworks-of-Women-with-Disabilities.pdf 
Singh, A. (2019). Psychosocial Support For Children: A Rapid Needs Assessment In North-East Nigeria. UNICEF.

https://www.unicef.org/nigeria/media/2956/file/PSS\%20Assesment\%20Report.pdf

Sphere Association. (2018). The Sphere Handbook: Humanitarian Charter and Minimum Standards in Humanitarian Response, fourth edition. Geneva: Switzerland. www.spherestandards.org/handbook

Taylor-Robinson, S. D., \& Oleribe, O. (2016). Famine and disease in Nigerian refugee camps for internally displaced peoples: A sad reflection of our times. QJM, 109(12), 831-834. https://doi.org/10.1093/qjmed/hcw171

Tirfessa, K., Lund, C., Medhin, G., Hailemichael, Y., Fekadu, A., \& Hanlon, C. (2017). Food insecurity among people with severe mental disorder in a rural Ethiopian setting: a comparative, population-based study. Epidemiol. Psychiatr. Sci. 1-11. https://doi.org/10.1017/S2045796017000701

UN Women. (2015). The Effect of Gender Equality Programming on Humanitarian Outcomes. UN WOMEN. https://www.unwomen.org//media/headquarters/attachments/sections/library/publications/2015/unw\%20effects\%20of\%20 gender\%20equlaity\%20on\%20humanitarian\%20outcomessinglepgsweb.pdf?la=en\&vs=5705

UNDESA. (2019). Disability and Development Report: realising the Sustainable Development Goals by, for and with persons with disabilities 2018. United Nations Department of Economic and Social Affairs https://social.un.org/publications/UN-Flagship-ReportDisability-Final.pdf

UNDESA. (2020). Protecting and mobilizing youth in COVID-19 responses. Policy Brief 67. UN Department of Economic and Social Affairs (UNDESA). https://www.un.org/development/desa/dpad/wpcontent/uploads/sites/45/publication/PB_67. pdf

United Nations, \& World Bank. (2018). Pathways for Peace: Inclusive Approaches to Preventing Violent Conflict. Washington, DC: World Bank. https://openknowledge.worldbank.org/handle/10986/28337

UNPRPD, \& ILO. (2021). Social Protection Measures For Persons With Disabilities And Their Families In Response To The Covid-19 Crisis: An Updated Overview Of Trends. UN Partnership on the Rights of Persons with Disabilities and the Centre for Inclusive Policy for the International Labour Organization. https://www.socialprotection.org/gimi/RessourcePDF.action;jsessionid=Q7M4iGUnzTJw-J0tjGoHF28_LIOilCZyCIDjKQE6f047yfOlukO!1750948109?id=57373\#

von Grebmer, K., Bernstein, J., Alders, R., Dar, O., Kock, R., Rampa, F., ... \& Higgins, B. (2020). Global Hunger Index: One Decade to Zero Hunger: Linking Health and Sustainable Food Systems. Welthungerhilfe: Bonn, Germany. https://www.globalhungerindex.org/pdf/en/2020.pdf

WFP. (2015b). Vulnerability Analysis and Mapping Food Security Analysis at a glance. World Food Programme.

https://documents.wfp.org/stellent/groups/public/documents/communications/wfp252355.p df

WFP. (2020). Yemen mVAM Food Security and Vulnerability Update No.54 (July-AugustSeptember2020). World Food Programme. https://docs.wfp.org/api/documents/WFP0000120471/download/ 
WFP Gender Office. (2020). The Power of Gender Equality for Food Security: Closing another gender data gap with a new quantitative measure. Rome: World Food Programme. https://docs.wfp.org/api/documents/WFP-0000112500/download/

WFP, \& FAO. (2020). FAO-WFP early warning analysis of acute food insecurity hotspots: October 2020. Rome. https://doi.org/10.4060/cb1907en

WFP. (2015a). Resilience Context Analysis: Resilience to shocks that impact food security and nutrition in South Sudan. World Food Programme.

https://documents.wfp.org/stellent/groups/public/documents/ena/wfp284803.pdf

Winder Rossi, N., Spano, F., Sabates-Wheeler, R., Kohnstamm, S., \& Harvey, P. (2017). Social protection and resilience: supporting livelihoods in protracted crises and in fragile and humanitarian contexts. FAO. http://www.fao.org/3/i7606e/i7606e.pdf

Women Deliver. (2021). The Link Between Climate Change And Sexual And Reproductive Health And Rights. An Evidence Review. https://womendeliver.org/wpcontent/uploads/2021/02/Climate-Change-Report-1.pdf

\section{Acknowledgements}

We thank the following experts who voluntarily provided suggestions for relevant literature or other advice to the author to support the preparation of this report. The content of the report does not necessarily reflect the opinions of any of the experts consulted.

- Stephen Devereux, Institute of Development Studies

- $\quad$ Nisar Majid, Research Associate, London School of Economics and Political Science (LSE)

- Daniel Maxwell, Tufts University

\section{Suggested citation}

Carter, B., \& Kelly, L. (2021). Social inequalities and famine and food insecurity risk. K4D Helpdesk Report. Institute of Development Studies. DOI: 10.19088/K4D.2021.097 


\section{About this report}

This report is based on fourteen days of desk-based research. The K4D research helpdesk provides rapid syntheses of a selection of recent relevant literature and international expert thinking in response to specific questions relating to international development. For any enquiries, contact helpdesk@k4d.info.

K4D services are provided by a consortium of leading organisations working in international development, led by the Institute of Development Studies (IDS), with the Education Development Trust, Itad, University of Leeds Nuffield Centre for International Health and Development, Liverpool School of Tropical Medicine (LSTM), University of Birmingham International Development Department (IDD) and the University of Manchester Humanitarian and Conflict Response Institute (HCRI).

This report was prepared for the UK Government's Foreign, Commonwealth \& Development Office (FCDO) and its partners in support of pro-poor programmes. Except where otherwise stated, it is licensed for non-commercial purposes under the terms of the Open Government Licence v3.0. K4D cannot be held responsible for errors or any consequences arising from the use of information contained in this report. Any views and opinions expressed do not necessarily reflect those of FCDO, K4D or any other contributing organisation.

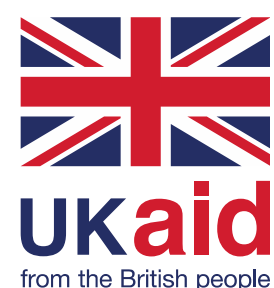

from the British people

(C) Crown copyright 2021. 